\title{
Speleothems in Cova des Pas de Vallgornera: their distribution and characteristics within an extensive coastal cave from the eogenetic karst of southern Mallorca (Western Mediterranean)
}

\author{
Antoni Merino ${ }^{1 *}$, Joaquín Ginés², Paola Tuccimei ${ }^{3}$, Michele Soligo ${ }^{3}$, and Joan J. Fornós ${ }^{4}$ \\ ${ }^{1}$ Grup Espeleològic de Llubí, Illes Balears, Spain \\ ${ }^{2}$ Federació Balear d'Espeleologia, Palma, Illes Balears, Spain \\ 3 Università "Roma Tre", Dipartimento di Scienze, Sezione di Scienze Geologiche, Largo San Leonardo Murialdo 1, 00146 Roma, Italy \\ ${ }^{4}$ Departament de Ciències de la Terra, Universitat de les Illes Balears, Ctra. Valldemossa km 7.5, 07122 Palma, Illes Balears, Spain
}

\begin{abstract}
The abundance and variety of speleothems are undoubtedly among the remarkable features of Cova des Pas de Vallgornera, the longest cave system in Mallorca Island developed in the eogenetic karst of its southern coast. Due to the monotonous carbonate lithology of the area, most of the speleothems are composed of calcite and in a few cases aragonite, although other minerals are also represented (e.g., gypsum, celestine, barite). However, in spite of the rather common mineralogy of the speleothems, its distribution results strongly mediated by the lithologic and textural variability linked to the architecture of the Upper Miocene reefal rocks. Apart from a vast majority of speleothem typologies that are ubiquitous all along the cave system, some particular types are restricted to specific sections of the cave. In its landward inner passages, formed in the low permeability back reef facies, a great variety of speleothems associated to perched freshwater accumulations stands out, as well as some non frequent crystallizations like for example cave rims. On the other hand, the seaward part of the cave (developed in the very porous reef front facies) hosts conspicuous phreatic overgrowths on speleothems (POS), which are discussed to show their applications to constrain sea level changes. The factors controlling the distribution of speleothems found in Cova des Pas de Vallgornera are discussed along the paper, focusing the attention on the lithologic, hydrogeologic, and speleogenetic conditionings; at the same time some uncommon speleothems, not found in any other cave in Mallorca, are also documented from this locality. Finally, a cognizant effort has been undertaken to illustrate with photographs the most remarkable speleothem types represented in the cave.
\end{abstract}

Keywords: speleothems, carbonate crystallizations, phreatic overgrowths, coastal karst, southern Mallorca

Received 5 October 2013; Revised 19 January 2014; Accepted 28 February 2014

Citation: Merino A., Ginés J., Tuccimei P., Soligo M. and Fornós J.J., 2014. Speleothems in Cova des Pas de Vallgornera: their distribution and characteristics within an extensive coastal cave from the eogenetic karst of southern Mallorca (Western Mediterranean). International Journal of Speleology, 43 (2) 125-142. Tampa, FL (USA) ISSN 0392-6672 http://dx.doi.org/10.5038/1827-806X.43.2.3

\section{INTRODUCTION}

The importance of Cova des Pas de Vallgornera is not only related to the extension attained by the cave itself (over $74 \mathrm{~km}$ of development), but also for the exceptional richness, striking variety, and abundance of speleothems. This wide exhibition of carbonate crystallizations is a common occurrence in Mallorcan karst areas (Ginés, 1995; Merino et al., 2011), but certainly this cave represents an exceptional case regarding this topic. As early as 2000, with the discovery and exploration of the Noves Extensions series (Fig. 1), this peculiar profusion and exhibition of speleothems was first highlighted (Merino, 2000). But it is not until the unexpected exploration breakthrough of 2004, when the hitherto unknown Descobriments 2004 series are discovered, that a full awareness for the spectacular display of speleothems is built (Merino et al., 2006). The discovery of abundant rimstone dams (gours) hosting a great number of other subaqueous types like shelfstones, cave rafts, cave cups, pool spar and, for instance, the existence of large areas of the cave covered in numerous capillary crystallizations like filiform and vermiform helictites- were showing 
a well-organized distribution of certain groups of speleothems. The finding of uncommon typologies, like cave rims, cave bubbles, pool fingers, and U-loops (to mention just a few of them) greatly enlarged the types of speleothems represented in Cova des Pas de Vallgornera (Merino, 2007b, 2008; Merino \& Fornós, 2010a), converting this cave in a unique locality within the Mallorca's endokarst.

Owing to the littoral character of the cave system, a special mention must be addressed to phreatic overgrowths on speleothems (POS). These carbonate encrustations have grown at the current sea-controlled water table (Tuccimei et al., 2010), recording in the same way ancient sea level positions (Dorale et al., 2010; Ginés et al., 2012b). The data supplied by the coastal phreatic speleothems from this cave are discussed in order to constrain sea level history during Pleistocene. Apart from the POS investigations, the only geochronological and paleoclimatological data produced on speleothems from this cave are those supplied by Hodge (2004), who studied three stalagmites whose chronology ranges from Middle Pleistocene to Holocene.

Regarding non-carbonate crystallizations, besides the scarce gypsum cave flowers reported in the cave (Merino, 2007b), detailed observations on cave rims shed light on a variety of unexpected minerals related to this particular morphological feature; strontianite, celestine, barite, and nordstrandite were identified (Merino et al., 2009), in a morphogenetic setting that points towards the actuation of hypogenic processes (Klimchouk, 2007).

Classifications of speleothems have been usually established on the basis of its morphology and/or the genetic mechanisms involved (Sweeting, 1973; White, 1976; Gillieson, 1996; Hill \& Forti, 1997; Ford \& Williams, 2007; Palmer, 2007). So, it is a common practice to systematize these deposits according to the characteristics of the water-flow that precipitates them; in this respect, speleothems formed by dripping waters, flowing waters and capillary or seepage waters are distinguished together with subaqueous crystallizations. All these categories are very wellrepresented in this exceptional cave by means of a great diversity of speleothem types, but their enumeration or even description is not the goal of this paper. In a more interpretative way, we will focus on the localization pattern of speleothems within the cave and on the factors that explain how they are distributed.

Commonly, all kinds of speleothems are present throughout the cave, but not in a rambling way. The lithologic and textural characteristics of the rock where the cave is located along with the proximity to the coastline and the complexity of the involved speleogenetic processes (Ginés et al, 2009a, 2009b), determine the presence and abundance of certain speleothems in specific sections of the cave system. The distribution of the speleothem typologies within Cova des Pas de Vallgornera will be the main target of this paper, together with the documentation of the most striking and/or uncommon crystallizations reported from this cave. In order to locate and identify the different sectors, main galleries, and chambers, a comprehensive article including a detailed description of the cave is also published in this issue (Merino et al., 2014). The totality of photographs included in the paper has been performed by one of the authors (AM) with the helpful collaboration of cavers from several clubs integrated within the Federació Balear d'Espeleologia.

\section{FACTORS THAT CONTROL THE DISTRIBUTION OF SPELEOTHEMS IN THE STUDIED CAVE}

Mallorca is a mid-latitude island $\left(39^{\circ} \mathrm{N}\right)$ located in a bioclimatic setting typically Mediterranean, with an annual average temperature of $16.6^{\circ} \mathrm{C}$ and a mean precipitation value near $600 \mathrm{~mm} / \mathrm{yr}$ (Guijarro, 1995); rainfall is markedly seasonal, showing its maximum in the autumn. The natural vegetation in the south of the island is dominated by semi-arid shrubberies and scarce forests that grow on thin calcareous soils. In general terms the present-day bioclimatic context favors the processes that generate speleothems, a situation that is extensive to the whole Mediterranean area. Furthermore, due to its position in the middle of the Western Mediterranean basin, Mallorca was not severely affected by the glacial periods during the Pleistocene (Ginés et al., 2012a), when the climate conditions were mostly mild but with important variation in precipitations. Although Th/U datings of stalagmites or flowstones from Mallorca are scarce (Hodge, 2004; Ginés et al., 2011), the deposition of speleothems during the cooler Pleistocene events is clearly documented by the presence of abundant speleothems, formed during low-stand sea levels, that are nowadays submerged in the present-day brackish pools of coastal caves like Cova des Pas de Vallgornera.

Apart from climate dependent controls, the formation of speleothems is also conditioned by the lithologic and textural characteristics of the rocks where the cave is located. Regarding their hydrogeological behavior, the Upper Miocene reefal carbonates that form the southern part of the island (Fornós et al., 2002) are an example of eogenetic karst, as defined by Vacher \& Mylroie (2002). The diagenetically immature limestone rocks, hosting the coastal karst areas of southern Mallorca, are characterized in general by high porosity and permeability values that certainly have some influences on the speleothem formation processes.

Another important factor, in this case intrinsic to the cave, is the great development attained by Cova des Pas de Vallgornera, with over $74 \mathrm{~km}$ of known passages and chambers. The very important extension of the cave system allows the existence of a great diversity of depositional environments, related to strictly topographic or morphogenetic conditionings, as well as to the wide textural variability of the rock as a function of the diverse facies observable within the Upper Miocene reef architecture (Pomar et al., 1996).

Centering our attention on lithology, two wellindividualized parts of the cave can be distinguished on the basis of the rock facies where their passages 


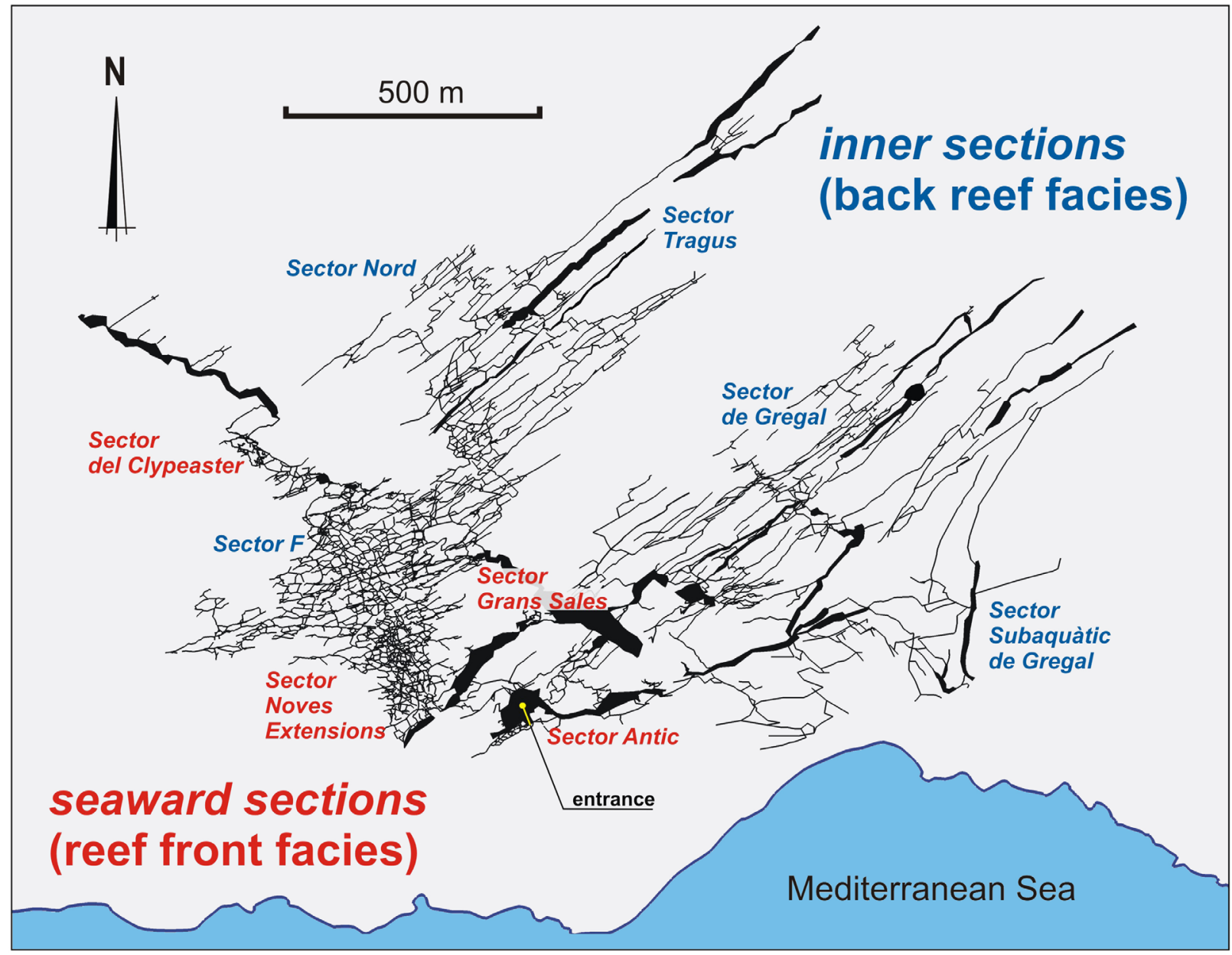

Fig. 1. Simplified survey of Cova des Pas de Vallgornera (Llucmajor, Mallorca) with indication of the sectors usually distinguished in the cave system as well as their correspondence with the two-fold lithologic units referred in the text.

are developed (Fig. 1). In this way, a very clear duality arises between the seaward sectors of the system and the inner landward passages (Ginés et al., 2009a). On the one hand, the sections of the cave closest to the coast-line (Sector Antic, Sector Noves Extensions, Sector Grans Sales and Sector del Clypeaster) are located in the reef front facies characterized by a very high primary porosity, along with an important secondary one linked to the dissolution of the aragonitic coral constructions. Within these reef front rocks, the spongework passages are dominant together with interspersed collapse chambers, all of them situated close to the water table corresponding to the present-day sea level. As opposite, the inner galleries are developed in the back reef carbonates, specifically in the outer lagoon facies (Pomar et al., 1996); in these less permeable rocks, that show a low primary porosity if compared with the reef front facies, the joint-controlled galleries are the rule, many of them forming an upper tier located +7 to $+11 \mathrm{~m}$ a.s.1. The back reef part of the cave (Fig. 1) includes basically the sections located towards the northeast (Sector Tragus, Sector Nord, Sector de Gregal and Sector Subaquàtic de Gregal); the upper tier maze (Sector F) is also developed in the back reef carbonates, owing to the existence of vertical facies variations controlled by the tridimensional reef architecture (Ginés et al., 2014). The substantial differences in porosity and permeability associated to the lithologic and textural variability of the Upper Miocene rocks are responsible for the morphogenetic duality referred above, which is discussed in depth by Ginés et al. (2014). This duality is also evident when explaining the speleothems distribution within the cave, as will be reviewed later on. The relative abundance of speleothems in connection with the distribution of rock facies within the cave is shown in the Table 1.

Yet it is possible to establish another important hydrological dichotomy concerning the characteristics of the water masses present in Cova des Pas de Vallgornera. The extensive brackish pools are distributed all along the cave, particularly in the sectors located closer to the coast-line, being evident that they are sea-controlled as tides and barometric sea level fluctuations can be observed. On the other hand, large extensions of passages forming the upper tier, in the inner part of the cave, are occupied by remarkable freshwater bodies. This fact seems to be related to the low permeability of the back reef facies, where the passage's floors easily become impervious due to carbonate deposition and significant perched freshwater masses occur, forming extensive gours. This additional dichotomy, in some manner rather coincident with the lithologic duality, has a clear repercussion on the characteristics of the subaqueous speleothems formed in each case.

A last factor that must be taken into account deals with some particular morphogenetic aspects of the inner passages. The complex speleogenetic mechanisms that formed the cave system include 
Table 1. Relative abundance of speleothems in connection with the distribution of facies within the cave. (XXXX: abundant; XXX: frequent; $\mathrm{XX}$ : occasional; $\mathrm{X}$ : rare).

\begin{tabular}{|c|c|c|}
\hline Speleothem & Back reef facies & Reef front facies \\
\hline \multicolumn{3}{|c|}{ Dripping and flowing water speleothems } \\
\hline Stalactites & $x x x x$ & $x x x x$ \\
\hline Soda straw & $x x x$ & $x x x x$ \\
\hline Stalagmites & $x x x x$ & $x x x x$ \\
\hline Columns & $x x x$ & $x x x$ \\
\hline Conulites & $x x$ & $x$ \\
\hline Flowstone & $x x x x$ & $x x x x$ \\
\hline Draperies & $x x x x$ & $x x x$ \\
\hline \multicolumn{3}{|c|}{ Capillary speleothems and botryoidal forms } \\
\hline Helictites & $x x x$ & $x x x x$ \\
\hline Antler helictites & $\mathrm{x}$ & \\
\hline Coralloids & $x x x$ & $x x x x$ \\
\hline Frostwork & $x$ & $\mathrm{x}$ \\
\hline Drip cones & $x$ & $\mathrm{x}$ \\
\hline Shields & $x x x$ & $x x x$ \\
\hline Cave rims & $x x x$ & \\
\hline Moonmilk & $x x x x$ & $x x x x$ \\
\hline Vermiculations & $x x$ & \\
\hline Sandsicles & $x x$ & $x$ \\
\hline Cave flowers & $x x$ & \\
\hline \multicolumn{3}{|c|}{ Vadose subaqueous speleothems } \\
\hline Rimstone dams & $x x x x$ & $x x$ \\
\hline Pool spar & $x x x x$ & $x x$ \\
\hline Cave rafts & $\mathrm{xxx}$ & $\mathrm{x}$ \\
\hline Raft cones & $x x$ & $x$ \\
\hline Cave bubbles & $x$ & \\
\hline Shelfstones & $x x x$ & $x x$ \\
\hline Candlestick & $x x$ & \\
\hline Coke tables & $x x$ & \\
\hline Cave cups & $x x x$ & $\mathrm{x}$ \\
\hline Cave pearls & $x$ & \\
\hline Pool fingers & $\mathrm{x}$ & \\
\hline \multicolumn{3}{|c|}{ Phreatic speleothems } \\
\hline POS* $^{*}$ & & $x x x$ \\
\hline Cave clouds & $\mathrm{x}$ & \\
\hline Tower corals & $\mathrm{x}$ & \\
\hline
\end{tabular}

${ }^{*}$ Phreatic Overgrowths on Speleothems

a suite of features produced by a deep hypogenic recharge (Ginés et al., 2009b; Merino \& Fornós, 2010b; Fornós et al., 2011). Some of these feeder-like features allow the presence -in specific spots of the cave- of uncommon speleothems and crystallizations (Merino et al., 2009) that grow on these vent morphologies once they were air-filled as the water table moved to lower positions.

Taking into consideration the referred factors, speleothems can be organized in three different groups depending on their location within the cave. The first group encompasses ubiquitous speleothems like, for example, most of the dripping and flowing water typologies. The second one corresponds to speleothems mostly present in the inner areas of the cave at the upper tier, away from the coastline, where cave rims stand out along with a great variety of deposits associated to freshwater gours, among others. And finally, a third group formed by those speleothems developed in the cave areas closer to the coast-line, that are partially drowned by brackish waters where the precipitation of sea-controlled phreatic overgrowths (POS) occur, in the form of aragonite coatings and calcite macro crystalline overgrowths.

\section{SPELEOTHEMS THAT ARE UBIQUITOUS IN THE CAVE}

Within this category fall those speleothems that are more or less evenly distributed all along the cave system or show only a small variability regarding their spatial distribution. The vast majority of dripping and flowing water speleothems are ascribed to this category, together with several eccentric or erratic speleothems precipitated from capillary-fed waters.

In order to avoid terminology problems (for instance, the use of more or less local speleothem denominations or the utilization of terms coming from different sources) we have adopted the speleothems nomenclature used in Hill \& Forti (1997), considering this work the most comprehensive and updated effort on this topic.

\section{Dripping and flowing water speleothems}

Undoubtedly, stalactites, stalagmites, and columns are probably the most common speleothems in the cave. Those of reduced size are mainly present in small-scale passages where they can fill/block their entire section. Sectors like Grans Sales and Tragus where ceilings are $5 \mathrm{~m}$ high or higher, allow the growth of longer stalactites and columns; stalagmites and columns in these sectors can reach massive dimensions (e.g., Sala de les Columnes). Besides, totem-pole stalagmites of waxen-texture are also present. As a result of the textural characteristics of the Upper Miocene limestones, there is an abundance of soda straw stalactites particularly in the very porous reef front facies (Fig. 2). So, owing to the high primary porosity of the whole rock, magnificent closely spaced clusters of soda straw forests cover almost completely the ceiling of many passages and chambers; the length of straw stalactites vary from a few centimeters to nearly $4 \mathrm{~m}$. In the passages of the inner part of the cave, stalactites and dripping water types are usually arranged along joints and fractures.

Depending on the surface unevenness of ceilings and overhanging walls, draperies can develop complex curves and twists, being often translucent revealing bands of different colors and shape. Draperies are found all over the cave, from the small-size passages of Sector F, to the large galleries that form the Sector del Tragus where the high ceiling allows the growth of long assemblages of them. At some areas, draperies severely affected by decalcification processes show a whitish altered shape (Fig. 3); in many cases, their occurrence is related to dissolution by condensation waters.

Flowstones cover large extensions in the cave, and as a result of the great variety of situations in which this chemical precipitation takes place, a wide range of forms can occur. Depending on where flowstones are deposited, they can be put into two groups, the forms covering walls and those flooring 


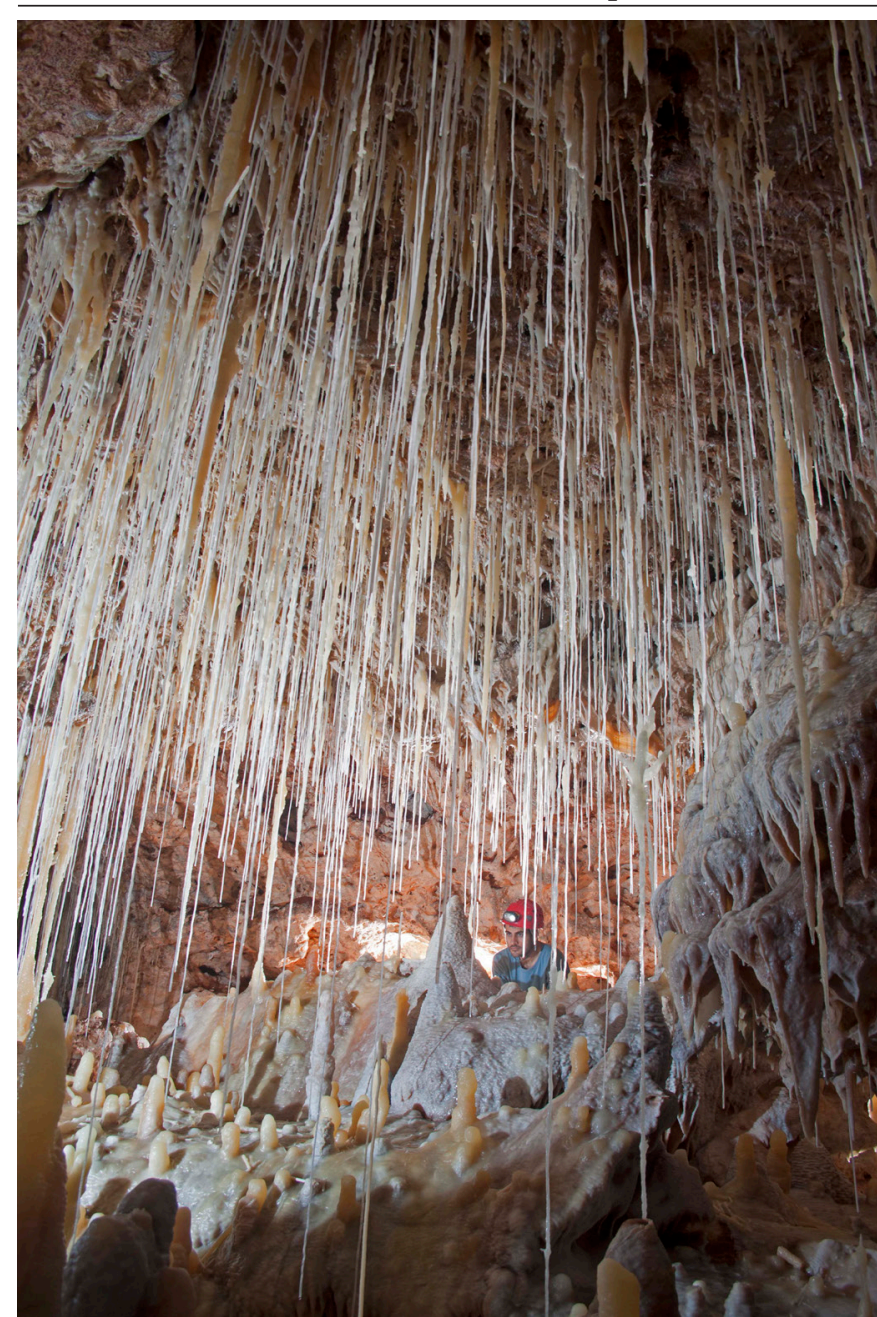

Fig. 2. Typical soda straw forest that decorates passages and chambers, some of them reach more than $3 \mathrm{~m}$ in length. Their abundance is related to the high porosity affecting the bedrock where the cave is developed.

passages and chambers. This speleothem can reach notable thickness covering and cementing the large accumulation of boulders that commonly floors breakdown chambers. When adjustment processes occur, flowstones are cracked and broken. At some locations the presence of massive deposits of flowstone can completely block passages. The existence of pristine custard-colored flowstones in the

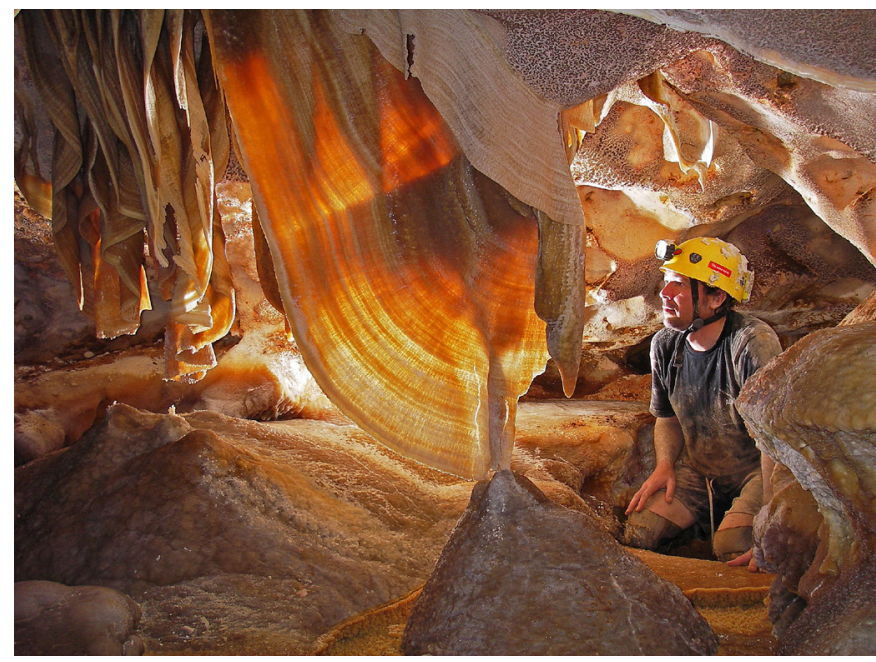

Fig. 3. Amazing drapery showing its translucent nature that unveils the bands of different colors that form this speleothem. To the left of the photo, a group of smaller draperies are affected by decalcification processes that have destroyed some small portions of them. passages of Sector del Tragus (Galeria del Gell, Galeria del Quilòmetre, and Galeria del Tragus) must be noted (Fig. 4). The presence of these conspicuous yellowish flowstones seems to be restricted to the landward part of the cave, probably due to the existence of welldeveloped organic soils at the surface, situation that does not occur over the sectors closer to the coastline.

\section{Erratic speleothems}

Certainly helictites, represented by very diverse varieties, are one of the most common speleothems in the cave and can be found covering floors, walls, columns and stalactites. Clustered bunches of helictites also occur at small spots or rock shelves. The length of helictites varies greatly, from $2 \mathrm{~mm}$ up to $25 \mathrm{~cm}$, being translucent, white or caramelcolored. Although they are especially abundant and variegated in the reef front carbonates (seaward part of the cave), in some passages of the inner sectors are quite spectacular, being frequently associated to cracks affecting flowstones that cover the passage's floors (Fig. 5). In the Gran Canyó Gallery (Sector del Tragus), filiform and vermiform helictites covering a rock shelf and its adjacent walls have been reported (Merino, 2006), being present as well in many other spots of the cave. An uncommon variety are the antler helictites, each the thickness of a pencil, protruding like a spear from a coating floor near Sector F (Fig. 6).

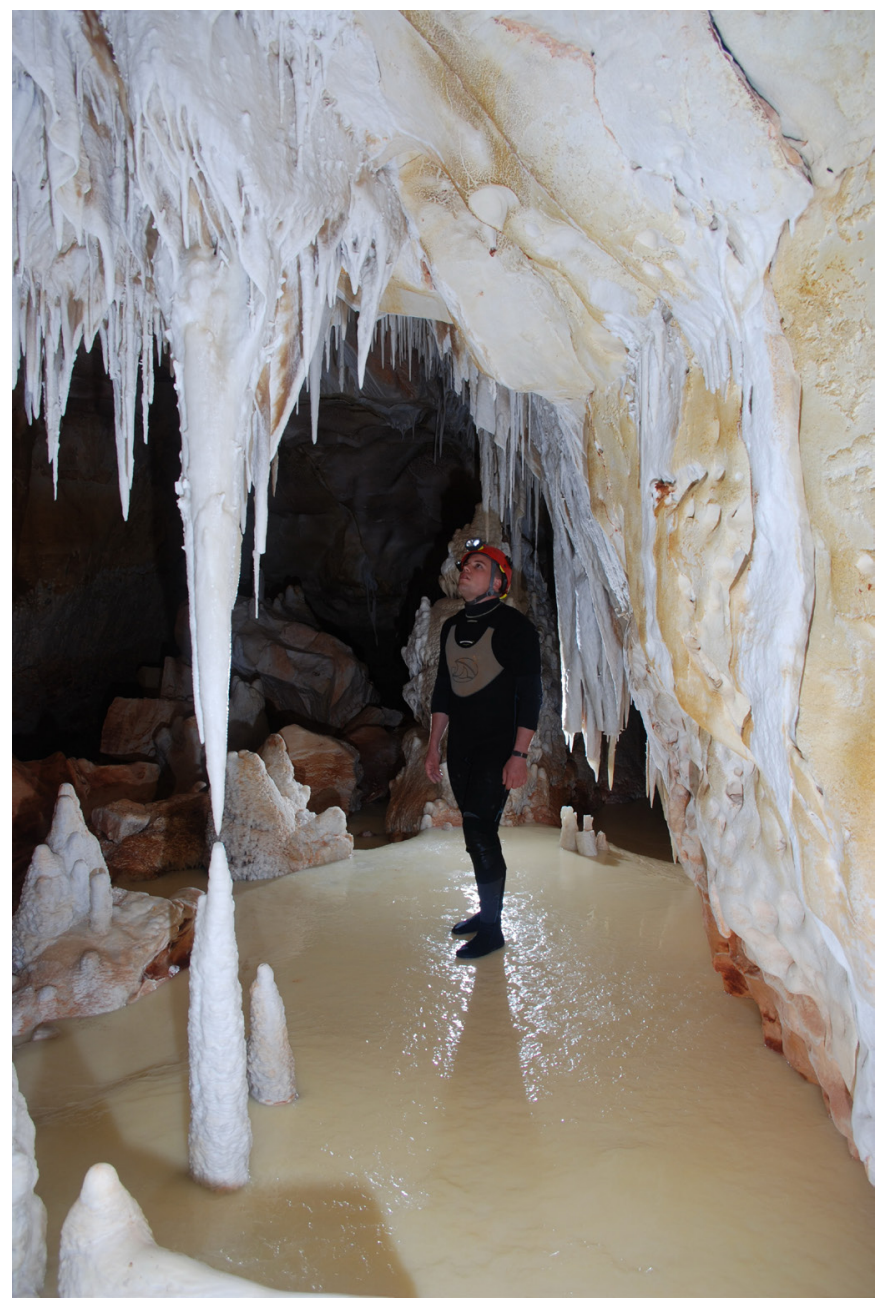

Fig. 4. Immaculate custard colored flowstone covering a section of a passage in Galeria del Quilòmetre. At the same time, a milky white stalactite-stalagmite assemblage is present. 


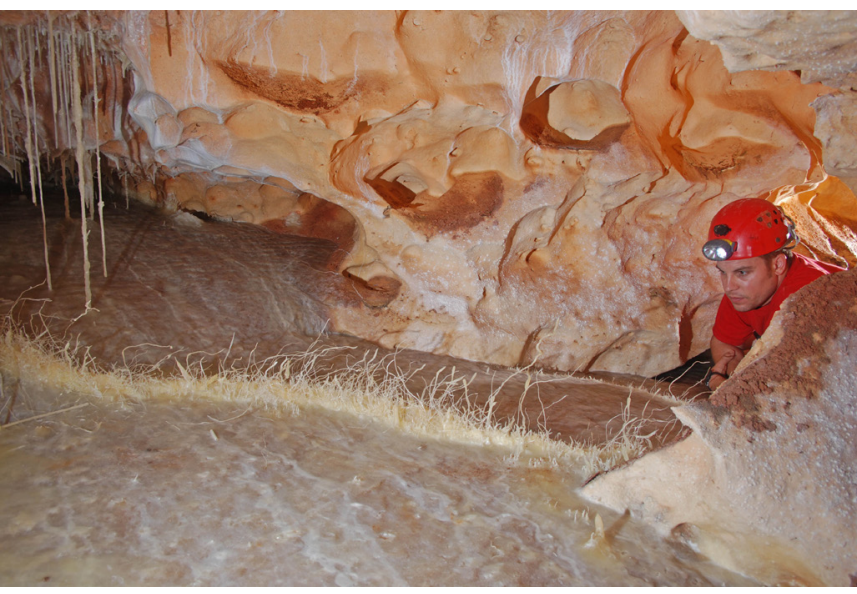

Fig. 5. A line of cream-colored vermiform helictites developed from a crack in the floor of a passage. They are oriented in a consistent direction, that could be influenced by air movements in the passage.

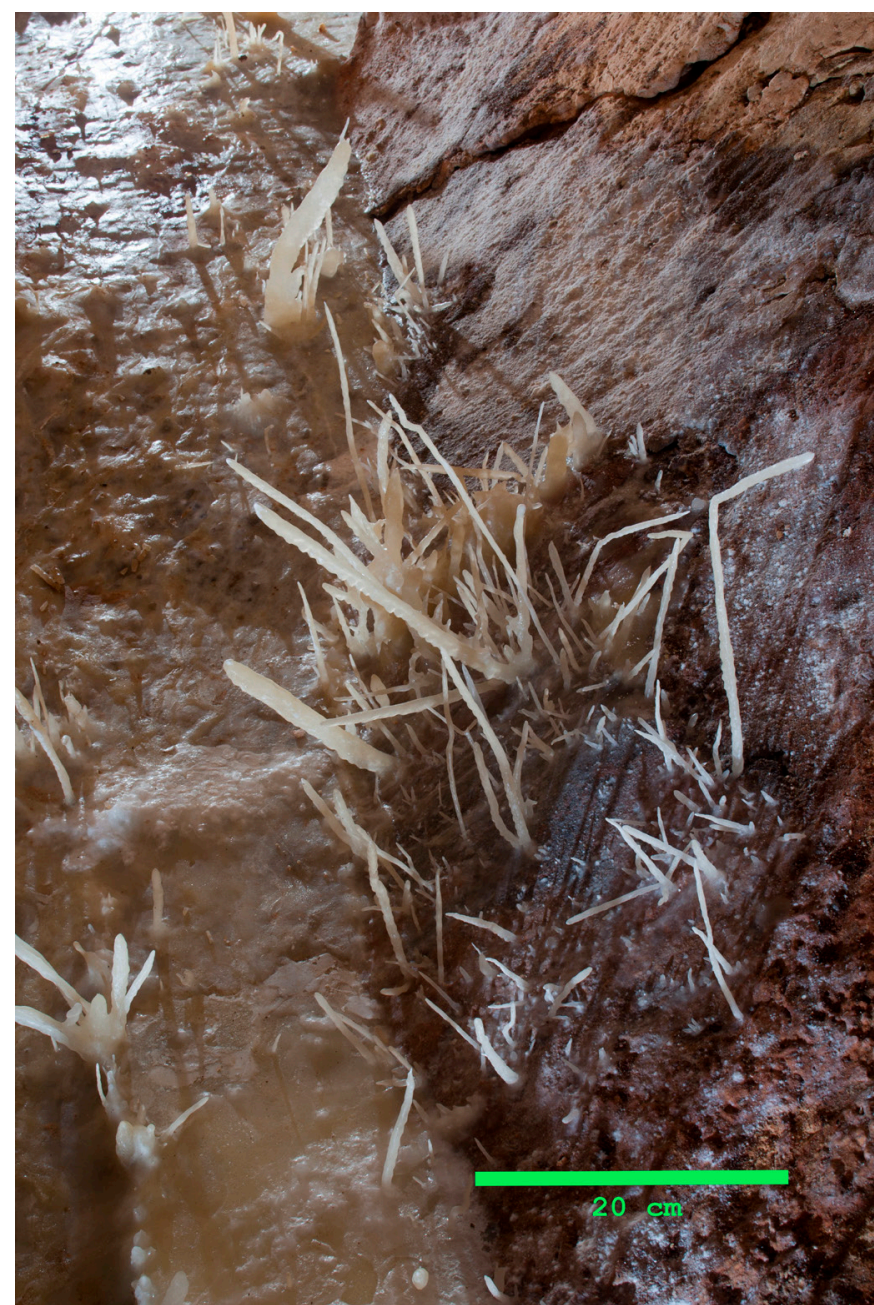

Fig. 6. A cluster of antler helictites growing from the wall bedrock and from a flowstone covering the floor of a small passage. Some of these rectilinear helictites resemble soda straw, while others are thicker and more crudely built.

Shields are not abundant but a few exemplars are distributed throughout the whole cave. They are composed of two parallel medallions of calcite separated by a thin fissure; through this internal crack a capillary seepage occurs, depositing calcite both sides and allowing the formation to grow vertically or at an oblique angle. Shields are commonly oval to circular, rarely exceeding $1 \mathrm{~m}$ in diameter, and quite often have other formations such as draperies or small stalagmites growing from them. A remarkable vertical oval shield, $2 \mathrm{~m}$ high and $20 \mathrm{~cm}$ thick, exists in Noves Extensions, showing the shape of a wall and partially blocking an aquatic passage.

In general terms, subaerial coralloids and botryoidal speleothems are exceptionally well-displayed in Sector Noves Extensions, Sector F, and Sector del Clypeaster, all developed in the high porous calcarenites of front reef facies, being present as well in almost all the other sectors of the cave. This kind of speleothems are formed by capillary waters seeping through the pores and minute fissures of the rock, without excluding the interaction with other mechanisms like dripping water splash and evaporation processes; all of them are responsible for a wide range of morphologies. The most common varieties are the branched globular and the grapes-like shaped coralloids. They range in size from a few millimeters up to $2 \mathrm{~cm}$ and are usually white or yellowish in color, with the latter ones having a waxen appearance (Merino, 2006). This kind of speleothem grows on walls, floor, on isolated boulders, or even on flowstones and stalagmites (Fig. 7).

\section{Other deposits and minerals}

Moonmilk is present in nearly all sectors of the cave; Sala del Moonmilk, Galeria del Quilòmetre, Galeria Navarrete, Sala que No Té Nom, and Sector $F$ are the areas where these deposits reach a wider distribution. Moonmilk occurs as a soft plastic and pasty coating growing over walls, ceiling and

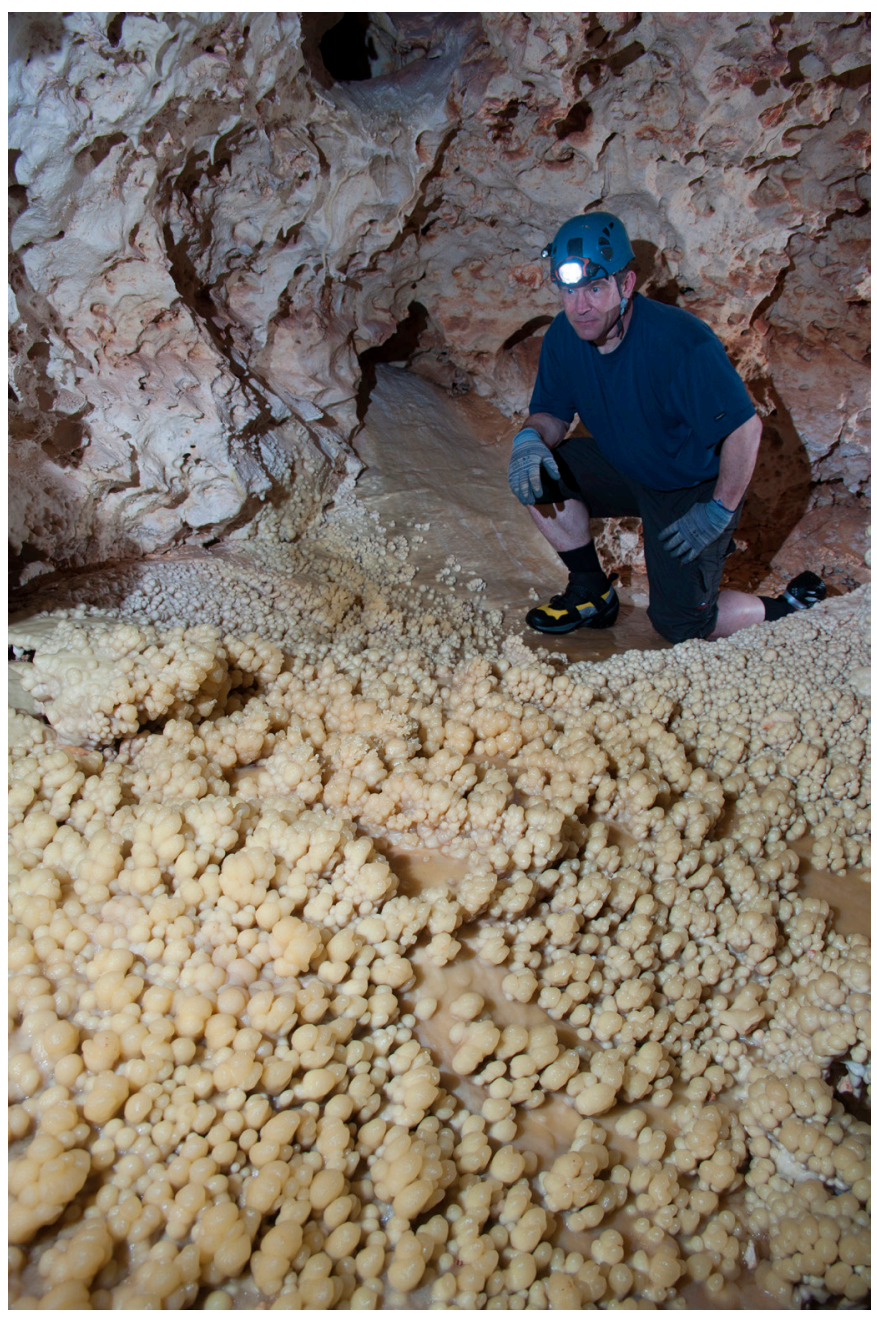

Fig. 7. The floor of a passage located in the highly porous reef front facies totally covered in coralloids. 
boulders. When wet it contains a high percentage of water (Sector F), on the contrary dry moonmilk is powdery, resembling chalk powder (Sala del Moonmilk, Galeria del Quilòmetre, Galeria Navarrete). It is composed of calcite and usually white in colour but at many locations presents a thin multicolored layer of corrosion residues, exhibiting changes in color from yellowish, greenish, and greyish to red. The thickness ranges from a typically $2-4$ $\mathrm{cm}$ to an exceptional $13 \mathrm{~cm}$ documented at the highest section of Sala que No Té Nom. These almost ubiquitous deposits may be originated as a result of particular physico-chemical conditions that lead to the degradation of bedrock, with the possible influence of biological processes caused by microorganisms (Hill \& Forti, 1997). This fact could be supported by the presence of the already mentioned corrosion residues that might be endproducts of microbially assisted dissolution and leaching of the rock (Northup et al., 2000, 2003; Spilde et al., 2005, 2006; Barton et al., 2007).

Composed of calcium sulfate, cave flowers are scarce in comparison with calcite speleothems (Merino, 2007a). They have been located in three different and distant areas of the cave. Firstly, at Sector del Clypeaster, few centimeters above the current water table level, secondly at Sector del Tragus and finally, at Sector F, the last two locations at the upper tier. These gypsum speleothems occur as thin translucent crust covering walls, as helical shaped formations and mainly as tiny flowers (Fig. 8). Cave flowers are commonly whitish in color, ranging from $2-3 \mathrm{~mm}$ up to $10 \mathrm{~mm}$ in length. They consist of variable number of crystalline fibrous petals that grow from a common center; these branching and curving bunches of parallel crystals show disparate lengths and thicknesses. This asymmetry seems to be caused by an unsteady growth. The genesis is likely to be controlled by seepage processes involving calcium sulfate solutions reaching walls and floors in the cave. A good example of this, would be the gypsum flowers and small crusts developed on a boulder partially submerged in the brackish waters at the Sector del Clypeaster.

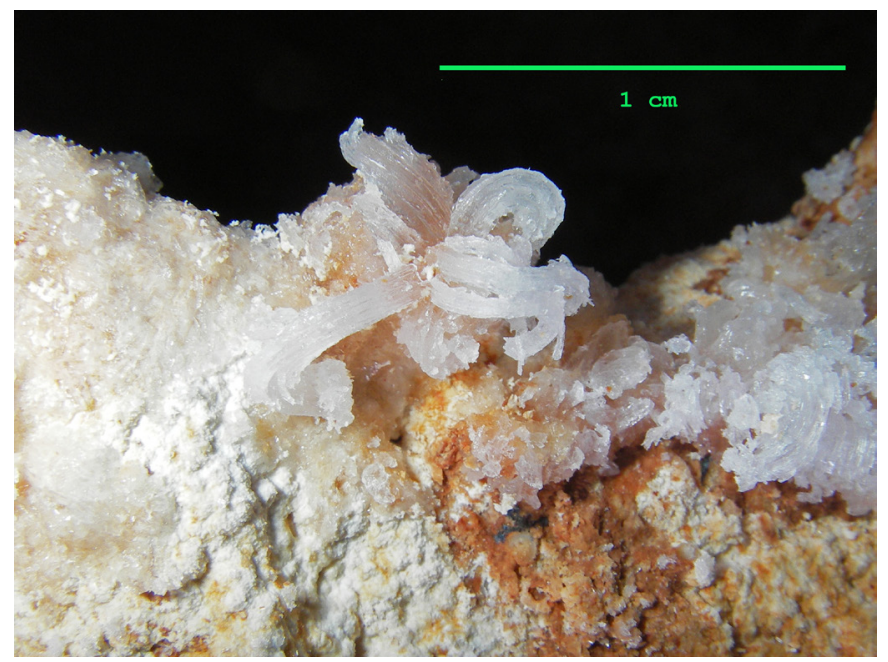

Fig. 8. Tiny cave flower composed of gypsum growing on the surface of a semi submerged boulder. Different calcium sulfate deposits can be seen around the area.

\section{SPELEOTHEMS WITHIN THE BACK REEF CARBONATES (LANDWARD SECTIONS OF THE CAVE)}

Many speleothem types and subtypes are exclusively represented in the inner galleries corresponding to the landward part of the cave system, which are developed in the back reef limestones characterized by a relatively low permeability (Ginés et al., 2009a, 2014). In some cases, their presence is not related to any lithologic or morphogenetic factor: it is exclusively the result of unusual speleothems growing in a particular spot of the cave, but without clear conditionings that explain their distribution. In some other typologies there is an evident connection between speleothem types and specific factors that determine their existence; this is the case of subaqueous speleothems precipitated in perched freshwater bodies existing almost exclusively in the upper tier of the landward passages. The distribution of the most characteristic speleothems that differentiate the two different lithologic units distinguished within the cave system is shown in Fig. 9.

\section{Dripping water speleothems}

Several subtypes of conulites are mainly found at the inner passages like Galeria del Tragus, where the massive accumulation of sediments and the height of the passage allow the growth of this speleothem. Typically, a conulite is a conical or cylindrical shell caused by dripping water and developed in soft material; the same water that excavates the hollow tube, splashes over it and coats a thin layer of calcite. The relatively calcisiltitic character of the back reef carbonates (outer lagoon facies, according to Pomar et al., 1996) could explain their development, linked to the silty residues resulting from the rock dissolution.

A variety of this formation, called bird-bath conulite occurs as an isolated speleothem or in groups of several individuals where sandy, silty and moonmilk deposits are present (Merino, 2006). Bowl-shaped, it is coated by a thick calcium carbonate layer that on the one hand, prevents the dripping water from seeping, and on the other allows to retain water for long periods of time. A radial structure caused by water splashes is noted; the range of them is related to the height between the dripping point and the floor, the higher the gallery, the wider the diameter of the speleothem.

Another peculiar kind of conulite developed on moonmilk has been discovered in Galeria del Quilometre, within the Sector de Gregal. It closely resembles the typical bird-bath conulite's morphology, but it does not contain water and a hollow tube of some centimeters in depth is present. A white vertical, gutter-shaped structure consisting of what appears to be moonmilk, grows over the hollow tube's mouth (Fig. 10). This unique speleothem is $8 \mathrm{~cm}$ in height, about $2 \mathrm{~cm}$ across its top and has a wall thickness of less than $0.5 \mathrm{~cm}$. The genesis could be related both to the materials that form the substratum and to the deposits that are washed away by dripping water. 


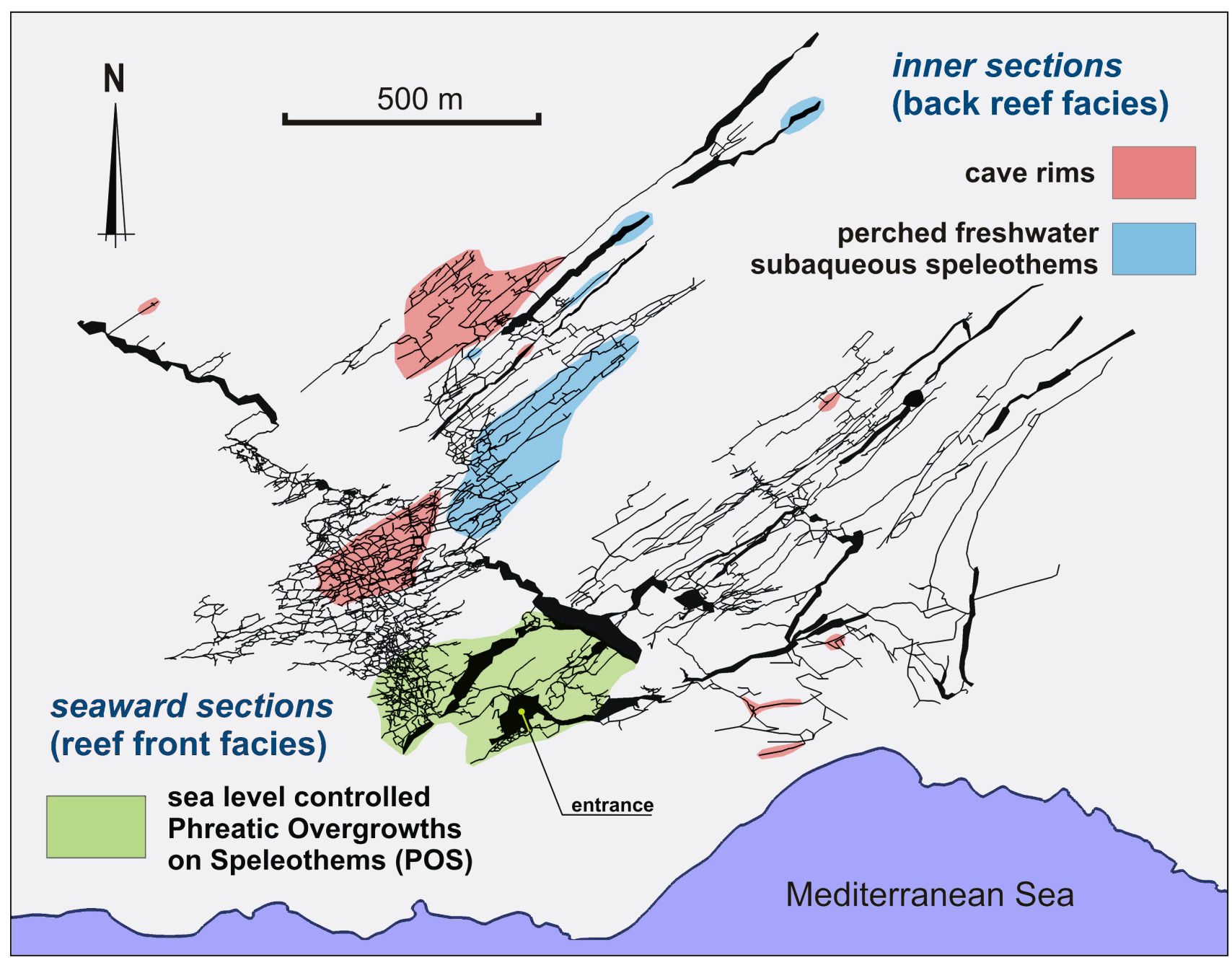

Fig. 9. Distribution of the most characteristic speleothems linked to the lithologic and morphogenetic dichotomy recognized in Cova des Pas de Vallgornera.

\section{Capillary speleothems}

Apart from subaerial coralloids and other botryoidal forms that are ubiquitous, frostwork is another speleothem with a similar genesis but composed of delicate white needles of aragonite (Merino, 2007a). It is quite scarce and has been found in Sector $F$ growing on white popcorns (Fig. 11). Occasionally the frostwork is formed by calcite as a consequence of a recrystallization process from aragonite while keeping the original needle-like shape (Palmer, 2007).

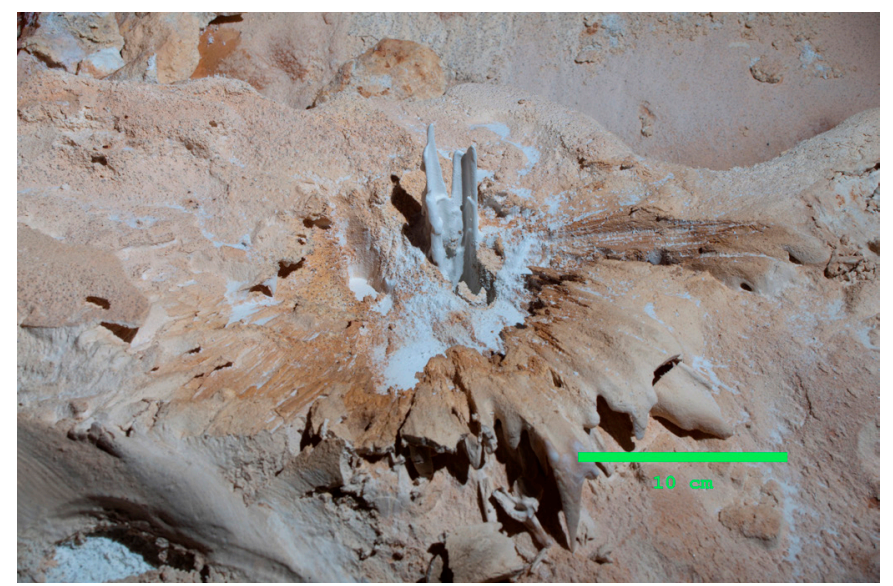

Fig. 10. Uncommon conulite developed on moonmilk, showing a peculiar white vertical shape composed of, what appears to be, moonmilk. Surrounding the area a radial structure caused by water splashes is clearly seen.

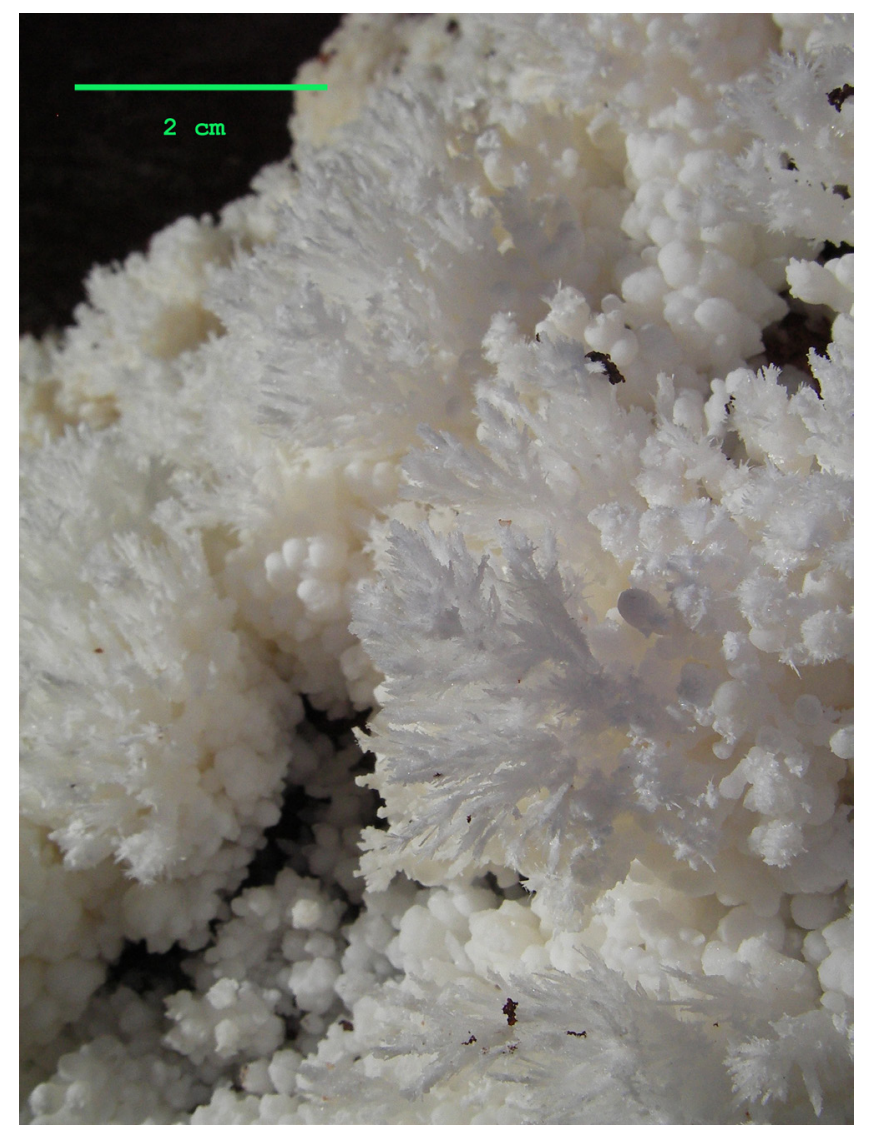

Fig. 11. Tiny aragonitic frostwork, resembling a small tree, growing on white pop-corns developed on a boulder. 


\section{Vadose subaqueous speleothems}

They are probably the most exceptional and one of the more varied categories of speleothems in the landward inner passages of Cova des Pas de Vallgornera. The richness of forms is favored, on the one hand, by the relative low permeability of the back reef facies that allows the accumulation of significant freshwater bodies on the floors of many galleries. On the other, the abundance of these temporary reservoirs of perched waters, distributed mainly along the sectors located at the upper tier (especially in Sector del Tragus and the maze of passages of Sector $F$ ), provides the right depositional environment for the development of numerous and variegated subaqueous formations. The following types have been described: rimstone dams (gours), pool spar, cave rafts, raft cones, cave bubbles, shelfstones, crescent shelfstones, candlesticks, coke tables, cave cups, pool fingers, and cave pearls (Merino, 2006).

Not only are rimstone dams (gours) the most abundant speleothems of this kind, but they also harbor the vast majority of the other types related to precipitation in this freshwater bodies. In Cova des Pas de Vallgornera, rimstone dams are mainly developed on gently sloping floors of ancient phreatic galleries currently located in the vadose zone. Most of them are lined with pool spar crystals of different sizes (Fig. 12). They are translucent, sometimes amber or yellowish in color, sharp-tipped calcite crystals that cover the whole pool sealing it and creating a perched pool. They have also been developed below shelfstones, growing on stalactites or on any formation submerged in pools.

As a consequence of the degassing of carbon dioxide at the pools surface, small calcite crystals form, floating by surface tension and joining together to create cave rafts. Floating rafts are normally small in size, with a thickness of about 1 millimeter or even thinner, whereas larger and thicker rafts are found attached to the pools walls or mostly sunk lying broken at the bottom of pools. Those thicker rafts show two different sides, the upper one is smooth and flat, whereas the lower one in contact with the water is coarse and covered by small calcite crystals. It is quite common to find dry pools with their shores and bottom covered in thin rafts. In spite of the fact that cave rafts are abundant, raft cones are generally rare in Cova des Pas de Vallgornera; only modest coneshaped piles have been found below drip points in passages from Sector del Tragus and Sector F.

One of the weirdest speleothems associated to rimstone dams observed in the cave are cave bubbles. They have been observed only in a small pool located at Sector del Clypeaster, (Merino, 2007a) and can be described as a hollow calcite concretion floating on a quiet and shallow pool. The precipitation takes place around a bubble of gas; they are ovoid or even close to hexagonal in shape, reaching $5 \mathrm{~mm}$ in diameter. The assemblage of cave bubbles is formed by hundreds of individuals that coalesce, most of them adhered to the side of the pool, others floating in the middle of

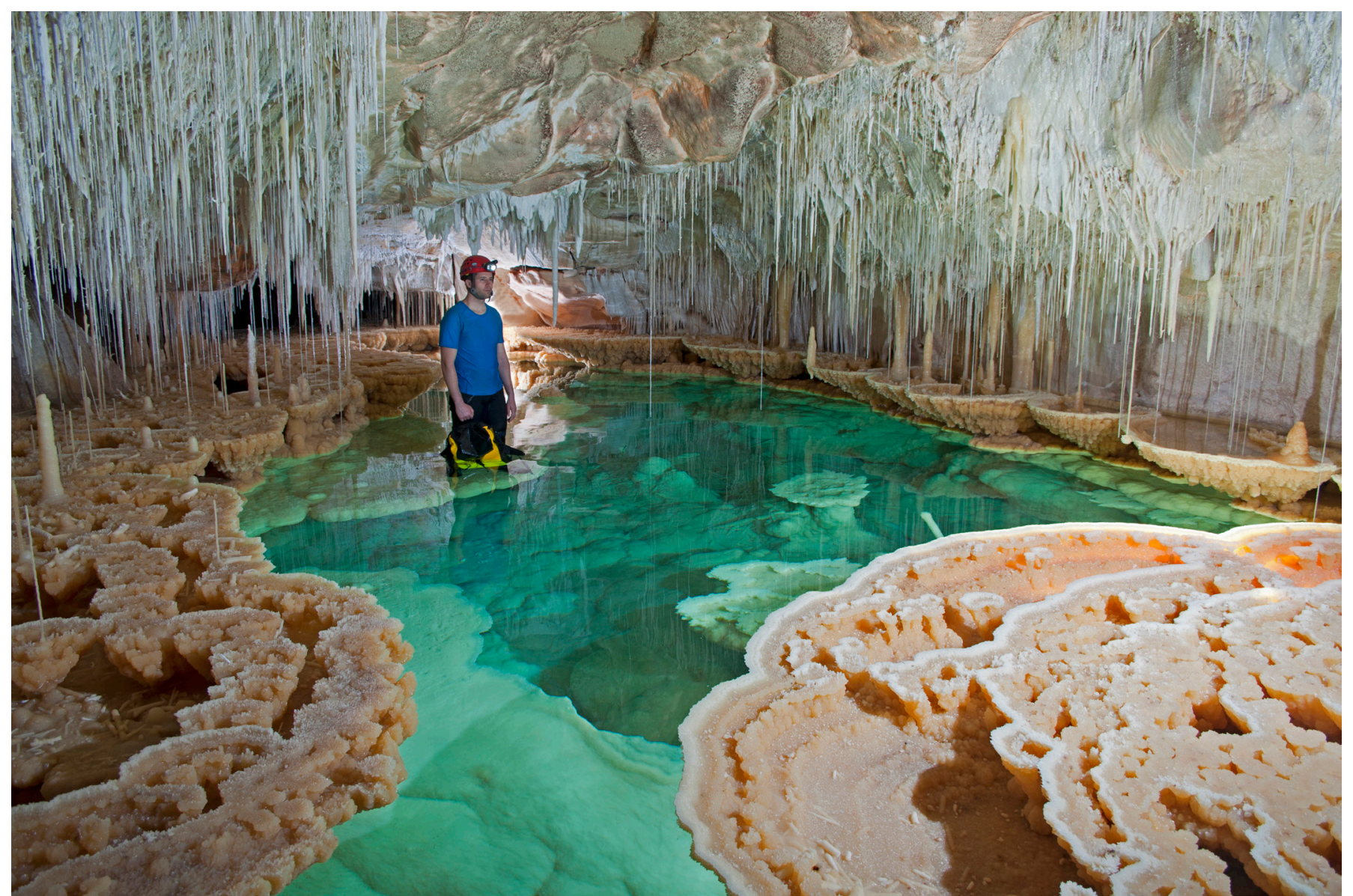

Fig. 12. Noteworthy rimstone dam located at the upper tier of the cave containing a wide range of other vadose subaqueous speleothems. A unique crescent shelfstones and lotus rimstones association rings the pool, these speleothems are formed by translucent crystalline calcite. Below the water surface, a calcite deposit coats the whole pool, sealing it and allowing the accumulation of freshwater. 
the water body (Fig. 13). The bubbles morphology is quite uniform, being their dimensions controlled by the concretion size. Clusters of cave bubbles are clearly separated one from each other by tiny gaps filled with water, while others show a higher concentration of individuals with the interstices filled with calcite (Fig. 14). At the same time, at the edge of those groups of bubbles, a cloud of what seem minute calcite crystals exists. Caves bubbles were located in a rimstone dam situated in a small alcove protected from air movements and without drips and were associated with other speleothems, like shelfstones and cave rafts, indicating highly saturated conditions. This special environment is necessary for the development of this fragile speleothem.

Because of carbonate precipitation taking place just at the water surface, a great number of rimstones are ringed by flat deposits of calcite attached as a projection or shelving to the edge of cave pools. These crystallizations, known generally as shelfstones, show a thickness that varies from a few millimeters up to several centimeters; it is quite common to find rimstone pools completely covered by shelfstones that show a decreasing of thickness to the centre of the pool.

The diversity of forms associated to the rimstone pools' surface is enormous in general, and this is particularly evident in Cova des Pas de Vallgornera. So, for instance, crescent shelfstones of different dimensions are also present in many cave pools; this rounded speleothem is caused by the interaction between dripping water and the pool itself. Therefore, the more stalactites or dripping points above the pool the more abundant crescent shelfstones are. Another variety of shelfstone present in the cave is the candlestick that forms surrounding small columns. One of the most outstanding and unique speleothems that occurs in the cave is the coke table. They are similar to a water lily-pad in shape, like a large plate that is close to $1 \mathrm{~m}$ in diameter and have been developed from a protruded half-submerged point inside a pool. They are quite flat and relatively smooth on the upper part, whereas the lower part is rough and formed by an aligned series of calcite macrocrystals. Similarly, others are developed around submerged stalactites tips.

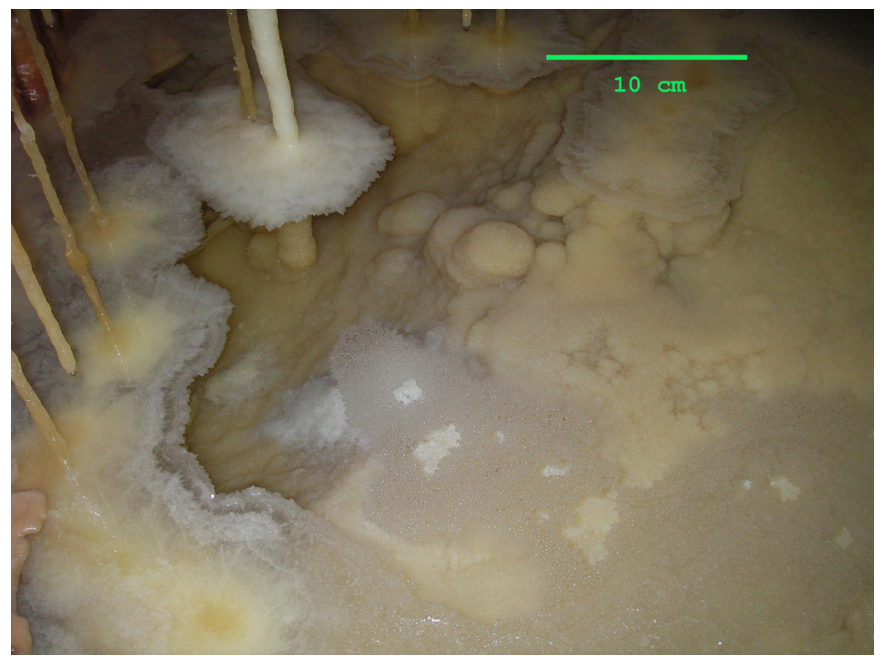

Fig. 13. A small rimstone dam harboring a myriad of minute cave bubbles.

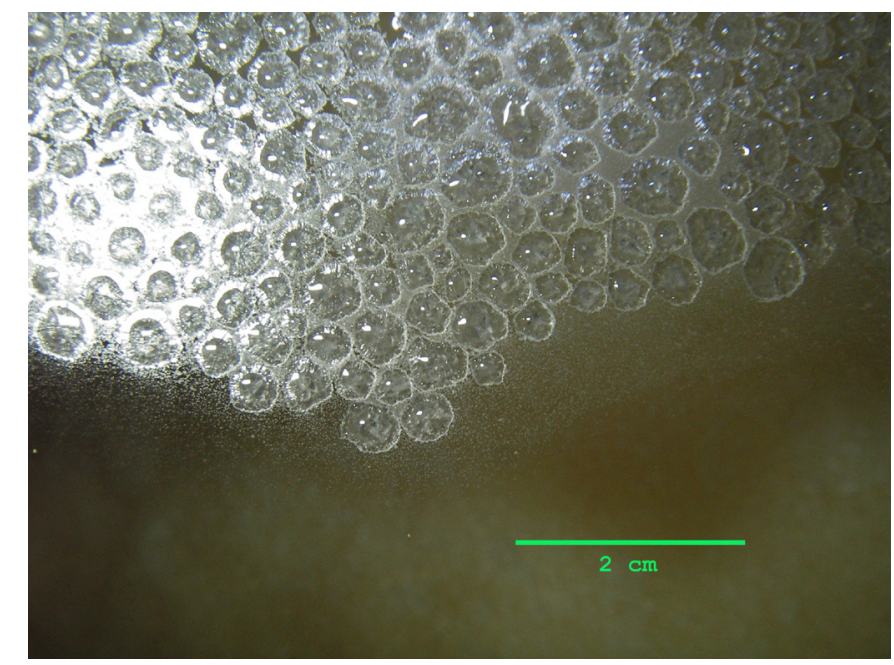

Fig. 14. Cave bubbles in detail. Different individuals coalesce showing a quite uniform dimensions and morphology. A constellation of what seems to be tiny calcite crystals is surrounding the group of cave bubbles.

A delicate and conspicuous kind of shelfstones are cave cups, which are spread in many shallow rimstone dams throughout the cave. They look like smooth concave dishes; some are round or elongated in shape, white translucent to yellowish in color (Fig. 15). The size ranges from $1 \mathrm{~cm}$ up to $20 \mathrm{~cm}$. The upper part of the cup is usually smooth, whereas small calcite crystals cover the lower one. They always form on the floor of cave pools, or as an eave-like projection from

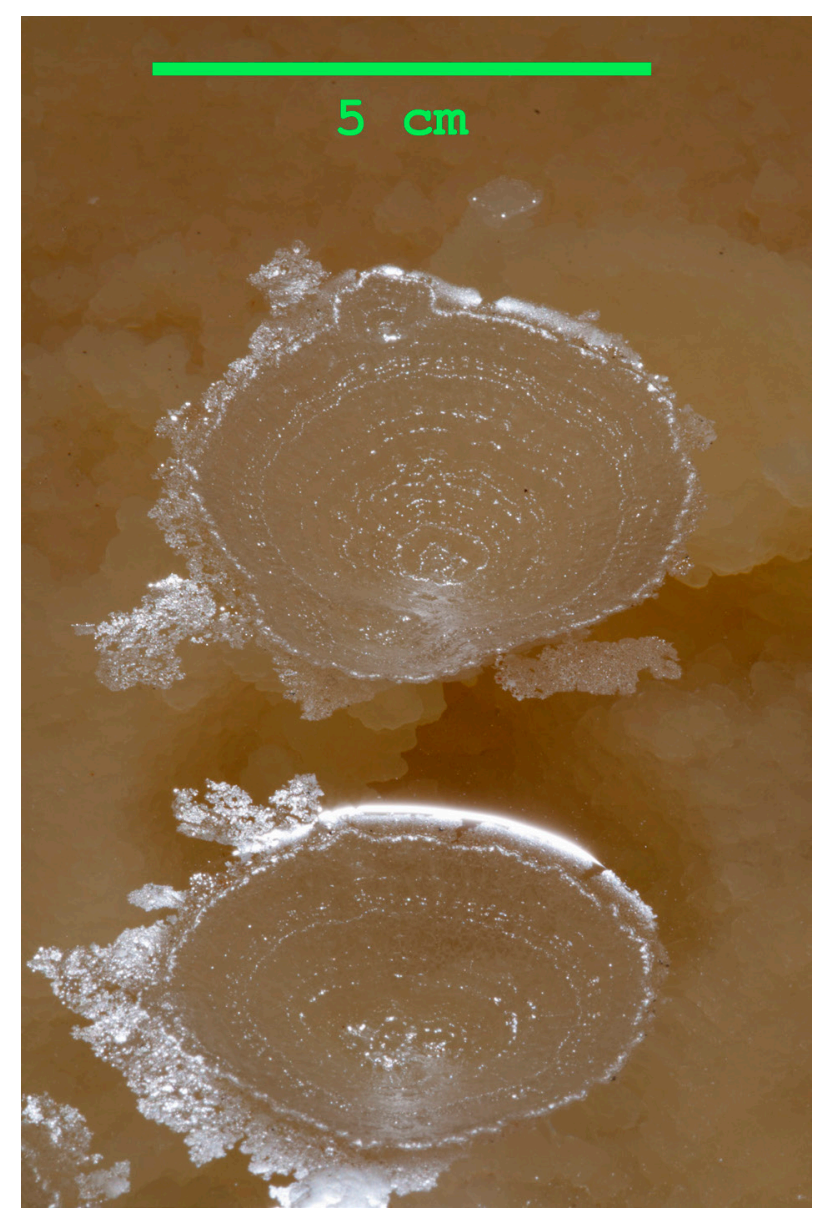

Fig. 15. Small-scale cave cups resembling smooth concave dishes. They are dry inside, in spite of the fact that the water level in the pool is just around the edge of the cups. The growing process of this speleothem is clearly exhibited by means of the tiny calcite rafts surrounding the cups and adhering to them. 
the wall of those pools. The former are attached to the floor by a peduncle that would be the cup's apex; the latter have grown from the pool's walls and are stuck to them. Generally, cave cups size is determined by the pools depth, the deeper the pool, the larger cave cups. Cave cups growing on the tip of calcite crystals or around a stalactite fragment in its center have been spotted in very shallow pools; these materials could be interpreted as acting as centers of precipitation for the speleothems to grow.

Also formed in shallow water accumulations, cave pearls are quite scarce, the only known locations being in Sector del Tragus and at the Galeria del Quilometre, normally associated with high ceilings and being developed in small pockets where water drips (Merino, 2008). They are round in shape like balls or elongated like rods when their origin is related to broken formations. The largest accumulation of cave pearls is in a series of micro rimstone dams, where they cover most of the surface, ranging from 1 to $3 \mathrm{~mm}$ in diameter.

Finally, pool fingers have only been located in an active pool, $9 \mathrm{~m}$ long $0.7 \mathrm{~m}$ in width and about $0.3 \mathrm{~m}$ deep, situated at the upper tier of the cave in Sector F. The pool is totally coated by pool spars and ringed with shelfstones and crescent shelfstones (Fig. 16). Pool fingers (Davis et al., 1990; Hill \& Forti, 1997; Palmer, 2007) resemble tiny stalactites formed subaqueously that are translucent and whitish in color, being developed on pool spars that cover the walls of the rimstone dam. They are elliptical in cross-section and with a diameter between 1 to $3 \mathrm{~mm}$; their length range from 1 to $30 \mathrm{~mm}$. Those pool fingers that currently have their tips submerged show a slight overgrowth. Moreover, very fine U-loops connecting fingers have been spotted (Merino \& Fornós, 2010a). These curved structures (Davis, 2000) are composed of small-sized calcite crystals that form bridges between adjacent fingers. Contrary to the existing pool fingers found in the caves of the Guadalupe mountains where microscopic bacteria filaments have been identified (Northup et al., 2000; Melin et al., 2001), those from Cova de Pas de Vallgornera, do not show any filaments or microbial remains after being studied with SEM (Merino \& Fornós, 2010a).

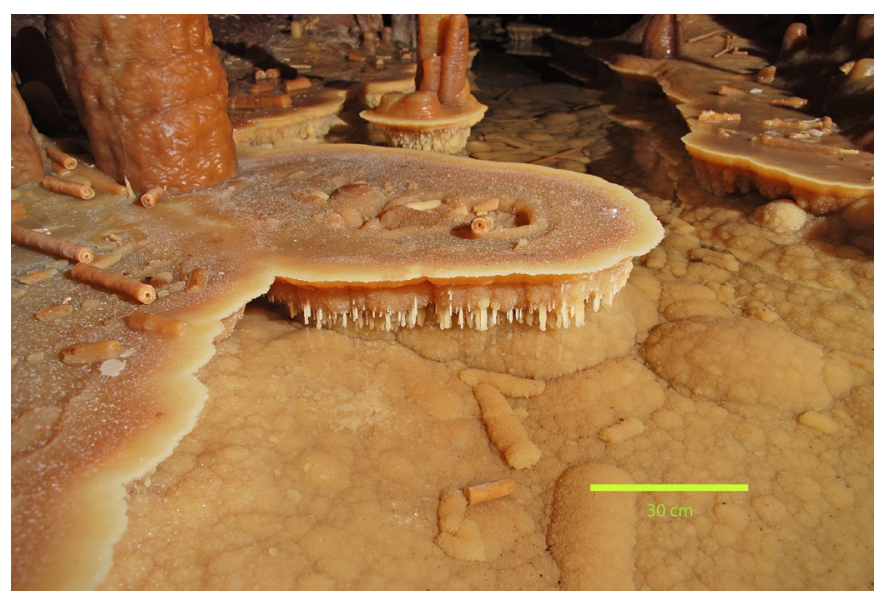

Fig. 16. Group of pool fingers hanging from the walls of an active rimstone dam. The whole pool is lined with pool spar.

\section{Phreatic crystallizations}

In the northernmost passage of the cave (Galeria del Tragus), the walls and floor of a relatively long stretch are coated by aragonitic mammillaries, forming rounded bulges that can be described as cave clouds. The coating is only a few centimeters thick and its upper limit determine a horizontal line, corresponding presumably to an ancient stabilization of the water table, approximately two meters above the passage's floor and $7 \mathrm{~m}$ above the current sea level. The phreatic character of these subaqueous deposits seems evident, taking into account their mineralogy (aragonite) and morphology (lack of shelfstone crystallizations that could point towards perched freshwater bodies). The lower sections of this aragonitic coating are affected by short and tiny upward rising solutional channels of likely hypogenic origin (Klimchouk, 2007). Although it is not clear if this mammillary coating was sea level controlled, it is obvious that lacks the characteristic shape related to the fluctuating tide-controlled water table, as will be described below when dealing with the phreatic overgrowths on speleothems (POS) existing in the seaward part of the cave system.

Within this aragonitic drained pool some exemplars of tower coral have been reported (Merino, 2006). This speleothem is quite scarce in the cave, and has only been located in the Galeria del Tragus so far (Fig. 17). Generally, the tower coral consist in groups of pinnacles that grow assembled on the floor and on boulders. The pinnacles are mainly found on the flatter areas of the passage where the surface inclination allows the accumulation of calcium carbonate. These speleothems grow upward being conical, small-towershaped, with uneven walls, being white or brown colored. Its dimensions range from a few centimeters up to $6 \mathrm{~cm}$ in height, and $3 \mathrm{~cm}$ in diameter; they are vertically oriented but if a drip occurs while growing it can cause the tower to be more irregular and to incline away from the vertical orientation. In cross-section the coral tower shows an aragonite radial structure being coated by a tough calcite outer layer. The genesis of this speleothem is related to the shallower areas of former ponds, corresponding to an ancient stabilization of the water table.

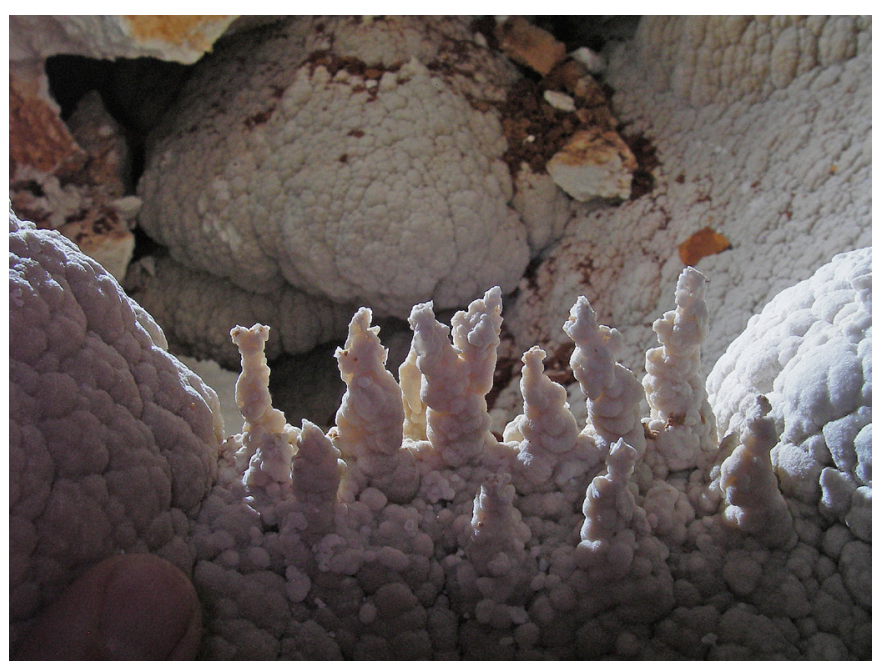

Fig. 17. Cluster of subaqueous Tower-Coral showing its typical conical small-tower shape. In cross-section this speleothem exhibits an aragonitic radial structure. 


\section{Cave rims}

Until very recently, this speleothem was unknown in Mallorca (Merino, 2006), being very well-represented in the inner sectors of Cova des Pas de Vallgornera. Cave rims have been located along the floor of Sector F, Sector Nord, Sector del Tragus (Galeria de les Toberes, Galeria d'en Pau, and Galeria del Tragus) and more recently in some underwater areas as for example Gran Canyó Gallery (Merino, 2006) and Sector dels Privilegiats, not ruling out the possibility of having a wider distribution throughout the underwater extensions. Cave rim morphology resembles a shell, being both sides of these projections strikingly different (Fig. 18). While the outside is rough and coralline, the inside is smooth, like the inside of the tube below the rim. Small and whitish crystallizations on the rim's edge have been noted. Rims occur around the lips of some rather vertical holes and cracks on the galleries' floor, referred as vents (Merino et al., 2009). White in color they reach a thickness of between 1 and 4 $\mathrm{cm}$. In addition to that, the nearby areas of the vents are normally rich in other mineral deposits such as gypsum precipitates, celestine crystals, white mineral aggregates composed of huntite and small Christmas tree-like aragonite (Merino et al., 2009; Onac et al., 2014). In general, the passages where this morphology has been found are small in size. It appears reasonably certain that these speleothems are mainly located in the upper maze area of this multi-storied cave, just above another tier, which is close to the current water table. Moist airflow from the lower tier to the upper

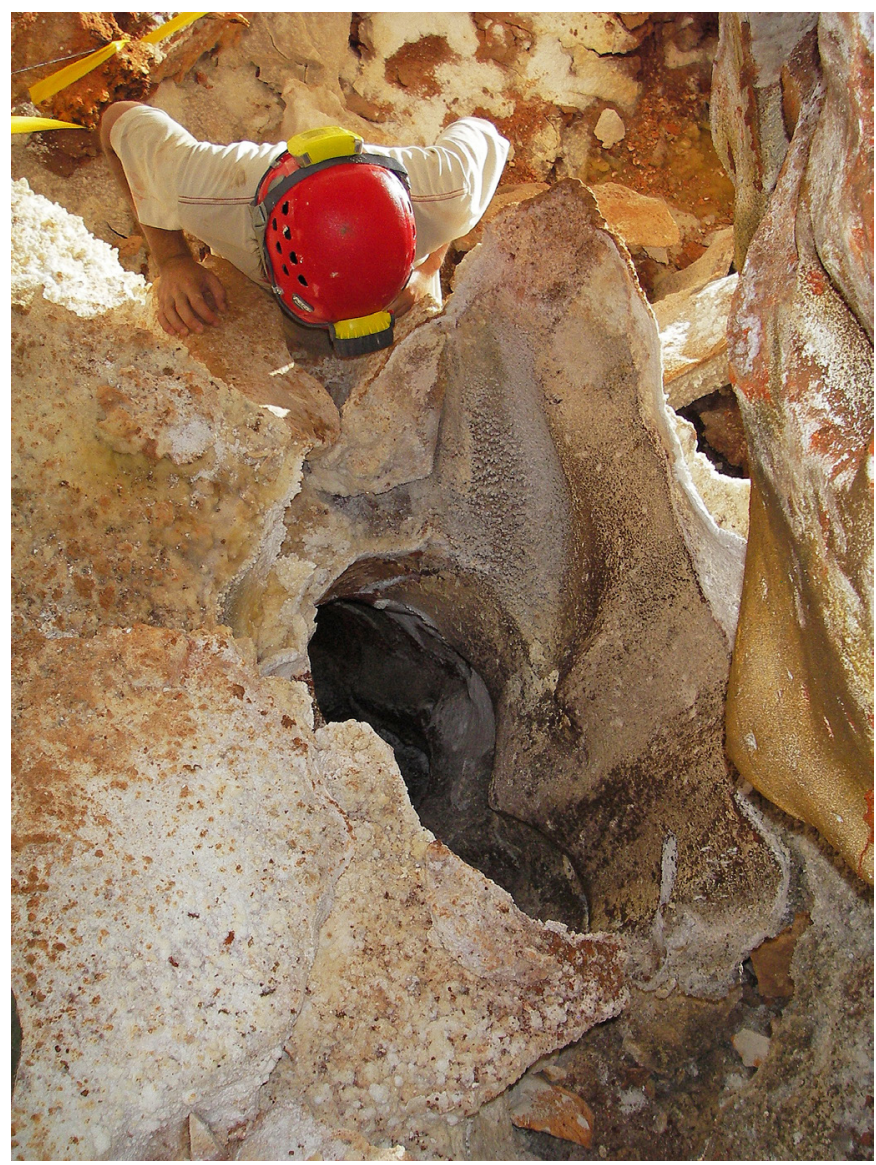

Fig. 18. Cave rim resembling a big white shell projecting from a vent in Sector del Tragus. The inner side shows a weathered and smooth surface covered with black-brownish corrosion residues, while the other side is rough and somewhat coralline with mineral deposits. one can cause the development of these rims, along with a combination of dissolution, weathering and deposition (Palmer, 2007).

The cave rims are developed on the upper top of rather vertical vents that presumably have acted as feeders (Klimchouk, 2007), related to a hypogenic basal recharge associated to geothermal phenomena (Ginés et al., 2009b, 2014; Merino \& Fornós, 2010b; Fornós et al., 2011). Thus, the distribution of this type of speleothem is not exclusively connected with the already mentioned lithologic factors, but also with speleogenetic constraints as, for example, the existence of specific hypogene features.

\section{Other deposits}

Associated with moonmilk coatings, vermiculations have also been found mainly at Galeria del Quilometre (Fig. 19). These formations cover ceilings and walls; they consist of irregular, thin, discontinuous deposits composed of brownish weathering residues (Merino, 2008). They range from a few millimeters up to $2 \mathrm{~cm}$ in length, reaching about $2-3 \mathrm{~mm}$ in thickness. Narrow white bands surround the colored deposits. Depending on the shape, they could be classified between leopard's spots and hieroglyphic vermiculations (Hill \& Forti, 1997). The origin of vermiculations in Cova des Pas de Vallgornera could be controlled by the presence of colored corrosion residues that are present over walls and ceilings covered with a moonmilk substrate. In an early stage, these weathering residues are adhered to a damp moonmilk substrate. Later, as a consequence of a change in the local climatic conditions of the cave, the moonmilk deposits dry out, causing them to shrink and therefore crack. Fissures provoke the falling of affected colored deposits and isolate the distinctive morphologies.

Another common formations related to the presence of moonmilk are sandsicles (Fig. 20) (Merino, 2007a). This tusked-shape speleothem is developed at the edge of flowstones or even on large boulders; they

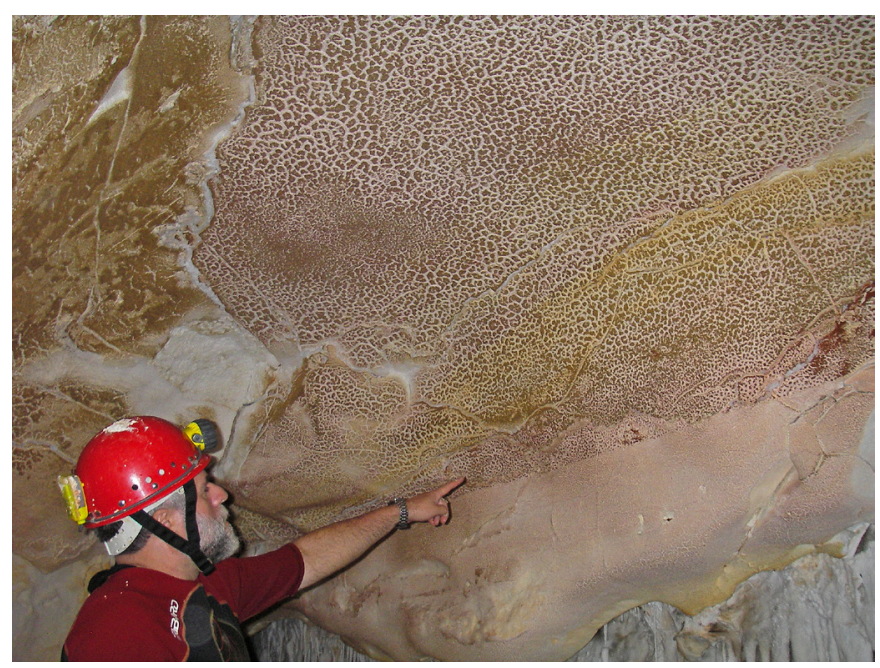

Fig. 19. Ceiling covered in vermiculations exhibiting the peculiar irregular morphology of these discontinuous deposits of brownish weathering residues. In the lower third of the photo a clear horizontal line marks the limit between the area covered by the speleothem and a blank surface. This can be related to an ancient stabilization level reached by the water table that could have erased or limited the development of vermiculations. 


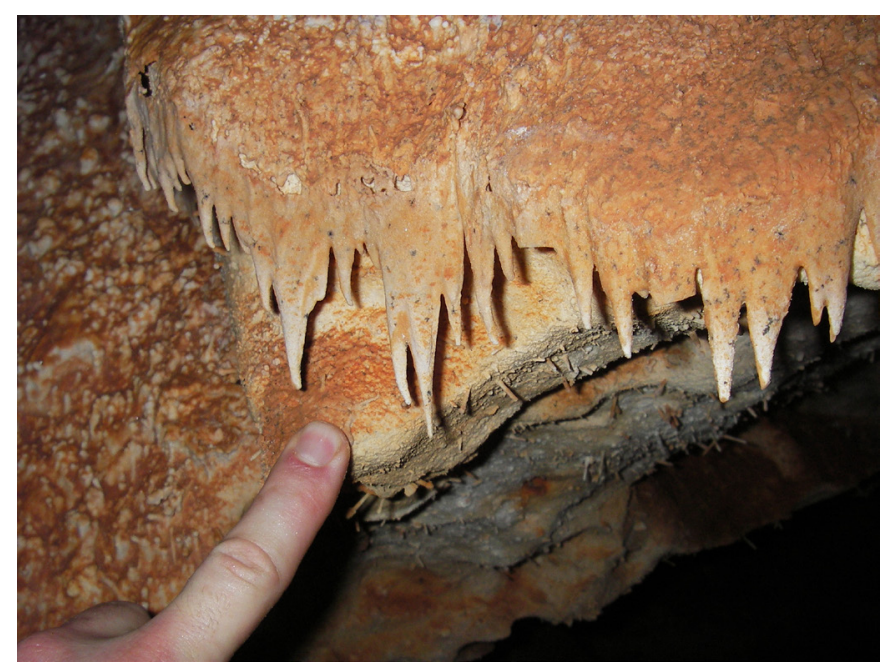

Fig. 20. Assemblage of colored sandsicles hanging on the edge of a boulder. This quite common speleothem is composed of calcium carbonate and it is present in many areas within the cave.

range up to $10 \mathrm{~cm}$ in length and color varies from dark brown to ochre. Sandsicles are composed of calcium carbonate and seem to be originated where ceilings and walls are covered in moonmilk, dry moonmilk powder or moonmilk-rich solutions that fall down or drip onto sloping flowstones. When the dense solution reaches the edge, impregnates it and begins to dry out depositing this tooth-like projections. The textural characteristics of the back reef facies seem to favor their presence owing to the silty material that results from the bedrock degradation.

\section{SPELEOTHEMS WITHIN THE REEF FRONT FACIES (SEAWARD SECTIONS OF THE CAVE)}

Most of the southwestern sectors of the cave develop within the Upper Miocene reef front, a rock facies that stands out by its very important primary porosity that configures a high permeability medium that becomes enhanced, moreover, by the dissolution of coral constructions. The high porosity of these carbonates, even at a matrix scale, is responsible for the particular occurrence of some speleothem types, like for example soda straw stalactites which cover large expanses of the cave ceilings but without being arranged along rock fractures (Fig. 2). Other kinds of crystallizations, like for instance the erratic features in general, are specially well-developed in these reef front limestones thanks to the capillary waters feeding the speleothems through the rock porosity. Additionally, the location of this lithologic unit in the seaward part of the cave constitutes an adequate hydrological and geochemical scenario where the precipitation of phreatic overgrowths on speleothems occurs (Ginés et al., 2013). The spatial distribution of these coastal subaqueous carbonate encrustations appears depicted in Fig. 9, being restricted to the brackish phreatic pools closer to the coastline.

\section{Erratic speleothems}

In spite of being previously referred as a ubiquitous speleothem, helictites are really very abundant and remarkable in the reef front carbonates, owing to the small-scale porosity of the rock. In this part of the cave, like for example in Sector Noves Extensions, wide extensions of its walls are fully covered by dense groups of vermiform and filiform helictites, which grow intermixed forming gorgeous and almost unbelievable assemblages (Fig. 21). Some of the walls that delimitate the Llac de na Gemma pool are really remarkable regarding the abundance and variety of tiny helictites.

Although not remarkable for its abundance, some drip cones of popcorn show a colorful shape and are mainly located in Sector del Clypeaster (Fig. 22) and the maze areas leading to it. In spite of the fact that they resemble hollow stalagmites, they are not classified as dripping water speleothems. Drip cones of popcorn are commonly formed where condensation water falls from points in the ceiling right above (Palmer, 2007). The highly aggressive subsaturated water dissolves the rock that forms the ceiling, provoking the development of a channel-like structure that concentrates the water drips to certain points. Small areas of the ceiling rock surrounded by those channels are fragile, soft and in some cases with a butter-like touch, being completely soaked in water. Provided the drips are undersaturated in calcite, no deposits form under the hitting point, on the contrary the growth of popcorn takes place as a result of evaporation processes around the affected area. When as a consequence of weathering, the dripping

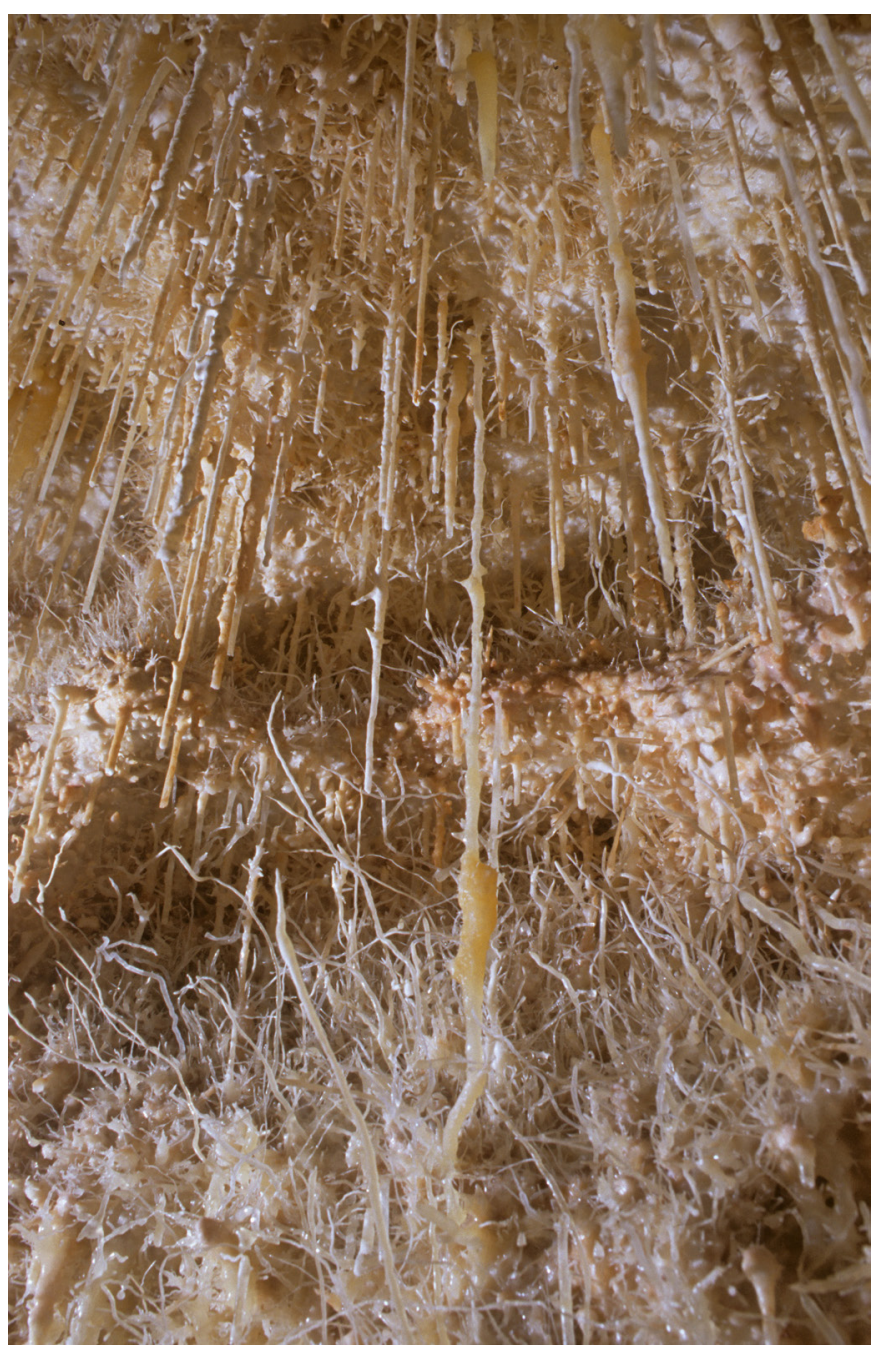

Fig. 21. Spectacular bunches of helictites extensively covering the walls in Sector Noves Extensions. 


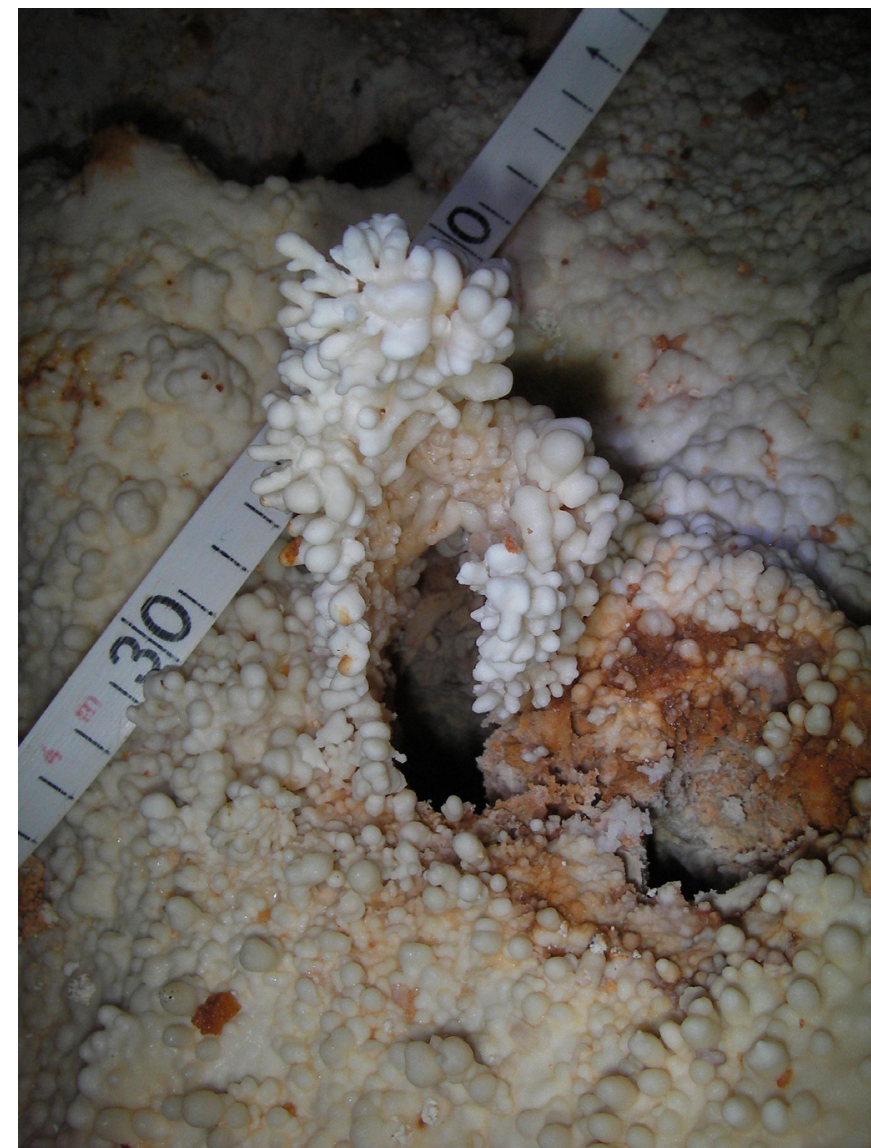

Fig. 22. Drip cone composed of coralloids expanding from a hole generated by drips of aggressive undersaturated water.

point in the ceiling shifts, the aggressive water is able to dissolve part of the cone causing a hollow canal.

\section{Phreatic Overgrowth on Speleothems (POS)}

Among the many carbonate precipitates found in Cova des Pas de Vallgornera, there are abundant aragonite deposits, formed at the surface of the brackish subterranean pools that are closer to the coast-line (Fig. 9). They include smooth yellowish aragonite overgrowths coating abundant delicate stalactites (Fig. 23), as well as stalagmites or the cave walls situated around the pools within the fluctuation range (tidal and/or barometric) of the current water table. These Phreatic Overgrowths on Speleothems (POS) form a bulky belt-like band deposited in correspondence to present-day sea level (see for example, Ginés et al., 1981; Pomar et al., 1979; Vesica et al., 2000). The largest thickness of these precipitates is located in the middle of the crystallization belt, gradually decreasing upward and downward (Tuccimei et al., 2010). Furthermore, several well-defined carbonate overgrowth horizons above the present-day sea level have been recognized in Cova des Pas de Vallgornera (Fig. 24), corresponding to past high sea stands (Pazzelli, 1999; Dorale et al., 2010; Ginés et al., 2012b). A single horizon of POS located at $-1 \mathrm{~m}$ below present sea level has been documented as evidence of a past low stand.

A short summary of investigations carried out on POS from Cova des Pas de Vallgornera is provided in the following paragraphs with the aim of showing their application to document past sea level change.

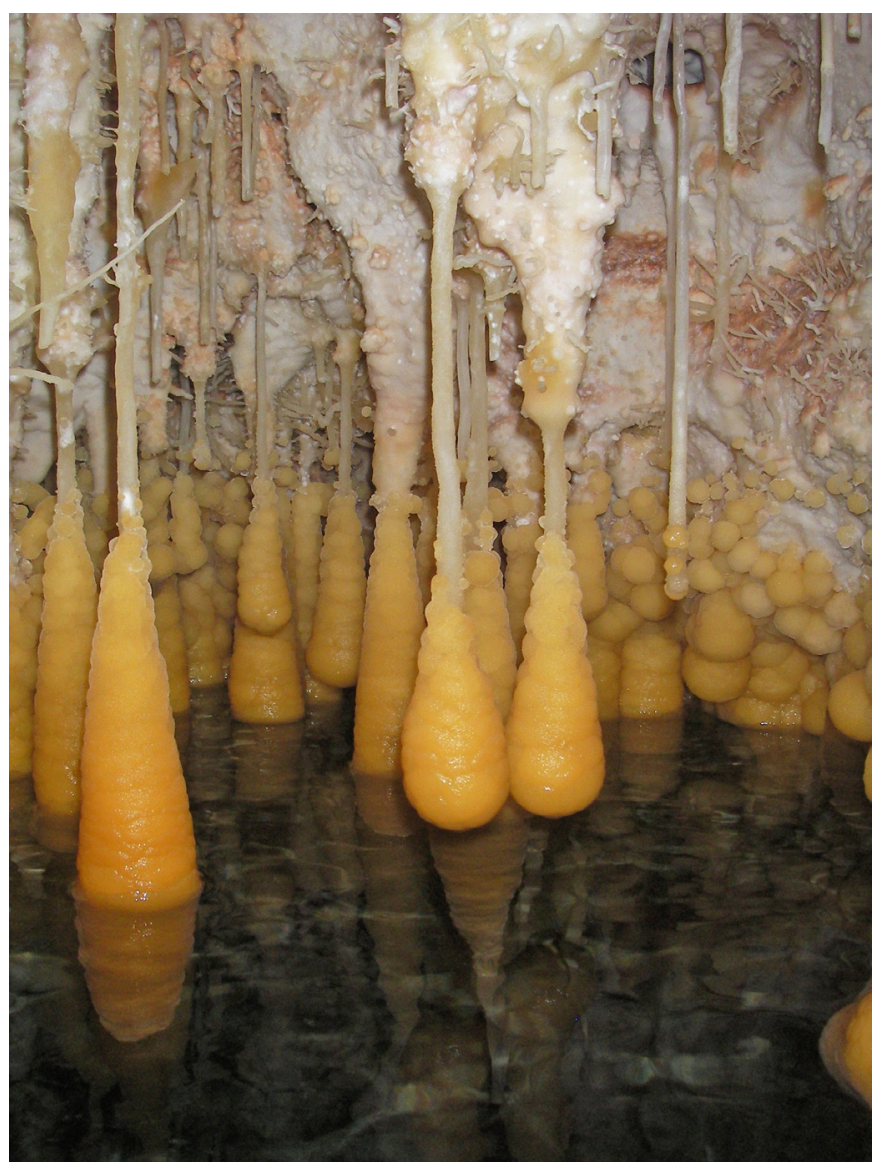

Fig. 23. Aragonite belt of POS at the surface of brackish pools from Sector Noves Extensions (width of the photo field $40 \mathrm{~cm}$ ).

\section{Holocene POS datings}

A bulky carbonate overgrowth covering a small stalactite at present-day sea level was sampled and studied to constrain Holocene sea level in Western Mediterranean. Once sectioned, the longitudinal view clearly showed the difference between the vadose speleothem (stalactite) and the phreatic precipitate (Fig. 25). The encrustation was a globular precipitate with a thickness of $0.5-2 \mathrm{~cm}$, composed of $20 \mu \mathrm{m}$ wide and $1 \mathrm{~mm}$ long acicular aragonite crystals with flat orthorhombic terminations, arranged in 0.3-1 $\mathrm{mm}$ thick successive growth bands of radial fan crystals. Five subsamples were drilled from the POS and dated by U-Th using ICP-MS (Inductively-Coupled Plasma Mass Spectrometry) (Fig. 25). They are characterized by high $U$ contents ranging from 7 to $9 \mathrm{ppm},{ }^{234} \mathrm{U} /{ }^{238} \mathrm{U}$ activity ratios approaching the value of 1.5 and very high ${ }^{230} \mathrm{Th} /{ }^{232} \mathrm{Th}$ activity ratios (always higher than 70). These data are evidence for very clean aragonite crystals forming from brackish water. The ages of subsamples 2, 4, and 5 (Fig. 25), drilled along the direction of the growth axis, are stratigraphically consistent, ranging from about $1.84 \pm 0.02$ to $0.61 \pm$ $0.01 \mathrm{ka}$. Two samples (1 and 3 ) from the innermost growth layer are undistinguishable from subsample 2 , giving ages around $2.0 \mathrm{ka}$. This demonstrates that the chemical system remained closed since deposition and no leaching or preferential dissolution occurred. It is worth noting that the extent of speleothem precipitation generally represents a minimum time interval for sea stand at that elevation, since the chemical properties of cave water can change 


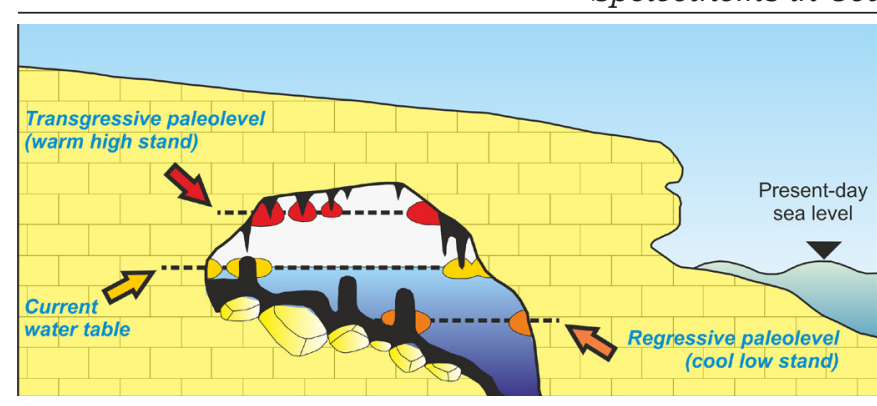

Fig. 24. Schematic cross-section through a coastal cave in Mallorca showing multiple levels of POS.

during sea stands, determining the end of POS growth, as occurred at about $0.6 \mathrm{ka}$ BP at Cova des Pas de Vallgornera (Table 2).

Internally consistent ages demonstrate that Holocene POS are readily datable by a U-series method. This also indicates that they are a useful indicator of past sea stands when these precipitates are found in coastal caves at different elevations above or below present marine level, as occurs today in Mallorca and also Sardinia (Vesica et al., 2000; Tuccimei et al., 2006; Tuccimei et al., 2012). A clear advantage of these carbonate materials over corals, vadose speleothems (drowned stalagmites) and marine overgrowths on speleothems, such as marine serpulides (Antonioli et al., 2004), is that POS mark with tight constraints sea level elevation at the time of their precipitation, whereas all the other kinds of carbonate precipitates give only an estimation of lower or upper limits reached by sea level. Furthermore, when compared with other precise morphological indicators of sea level, such as wave-cut notch or platform, POS have the advantage that they can be precisely datable using U-Th method (Tuccimei et al., 2010).
The same POS was also dated using AMS ${ }^{14} \mathrm{C}$ method (Tuccimei et al., 2011), but ${ }^{14} \mathrm{C}$ ages were consistently 2.3-2.4 ka older than the corresponding U-Th data, as shown by values of percent dead carbon proportions of $24.61 \pm 0.25$ and by high and correlated abundances of trace elements in the inner stalactite. This is due to the long residence time of groundwater in epikarst and soil, where the water interaction with soil and bedrock is responsible for the dissolution of ${ }^{14} \mathrm{C}$-free limestone and the following incorporation in the precipitate. Better results were obtained for POS from other caves in Mallorca (Cova de Cala Varques A) where the residence time of water infiltration through the soil and epikarst is short and the interaction with soil and bedrock is limited. In these cases the so-called "reservoir" effect is negligible and ${ }^{14} \mathrm{C}$ and $\mathrm{U}$-Th ages corresponds within the error range (Tuccimei et al., 2011).

\section{POS: a tool to constrain sea level history}

ICP-MS U-Th dating of late Holocene speleothem overgrowths forming at present-day sea level in Cova des Pas de Vallgornera and other coastal caves (Tuccimei et al., 2012; 2013) indicates that in the study region sea level reached the present level about 4,000 years ago. U-Th records were compared with the predicted curve of relative sea level change, due to glacial isostatic adjustment (GIA). SELEN was used for this purpose, a software for solving the "sea level equation", the law that governs the sea level variations associated with the melting of the Pleistocene ice sheets (Spada \& Stocchi, 2007). The modeling shows that Mallorca largely tracks the eustatic sea level curve, but the predicted present-

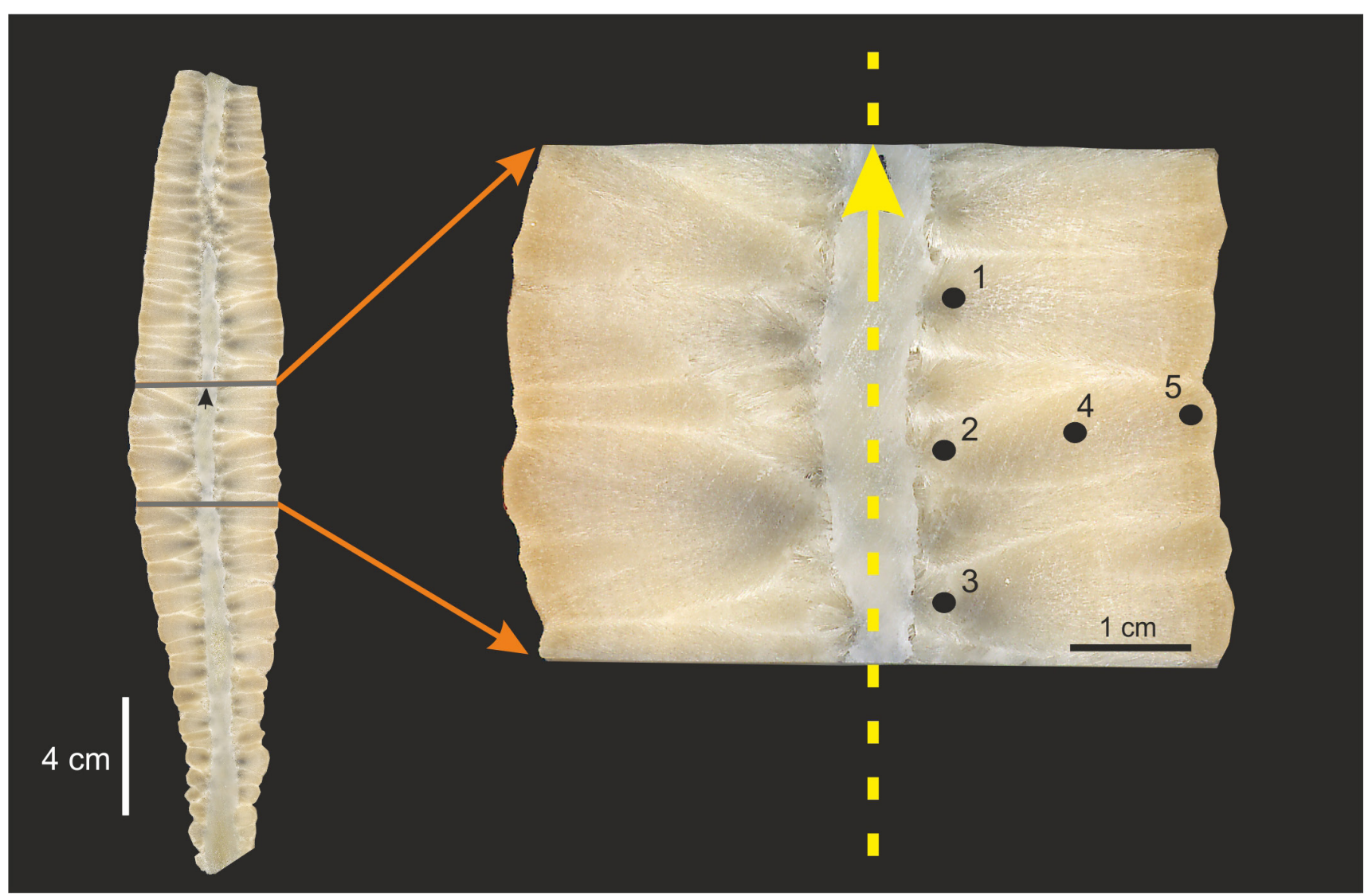

Fig. 25. Location of samples from a postglacial POS of Cova de Pas de Vallgornera, analysed for U/Th dating. Obtained ages range from 2.0 to 0.6 ka B.P. (after Tuccimei et al., 2010). 
Table 2. U-series data of Phreatic Overgrowths on Speleothems (POS) from Cova de Pas de Vallgornera.

\begin{tabular}{|c|c|c|c|c|c|c|c|c|}
\hline Sample & $\begin{array}{l}\text { Height } \\
\text { m (a.s.l.) }\end{array}$ & $\underset{(\mathrm{ppb})}{U}$ & ${ }^{234} \mathrm{U} /{ }^{238} \mathrm{U}$ & $\left({ }^{234} \mathrm{U} /{ }^{238} \mathrm{U}\right)_{0}$ & ${ }^{230} \mathrm{Th} /{ }^{232} \mathrm{Th}$ & ${ }^{230} \mathrm{Th} /{ }^{234} \mathrm{U}$ & ${ }^{230} \mathrm{Th} /{ }^{238} \mathrm{U}$ & $\begin{array}{c}\text { Age } \\
(k a)\end{array}$ \\
\hline VL-D3-1 \# a & \pm 0 & 8829 & $1.480 \pm 0.002$ & & $271 \pm 2$ & & $0.0262 \pm 0.0002$ & $1.9 \pm 0.01$ \\
\hline VL-D3-2 \# a & \pm 0 & 7396 & $1.478 \pm 0.002$ & & $69.3 \pm 0.4$ & & $0.0250 \pm 0.0002$ & $1.8 \pm 0.02$ \\
\hline VL-D3-3 \# a & \pm 0 & 8139 & $1.475 \pm 0.001$ & & $510 \pm 3$ & & $0.0264 \pm 0.0002$ & $2.0 \pm 0.01$ \\
\hline VL-D3-4 \# a & \pm 0 & 8217 & $1.487 \pm 0.001$ & & $457 \pm 3$ & & $0.0183 \pm 0.0001$ & $1.4 \pm 0.01$ \\
\hline VL-D3-5 \# a & \pm 0 & 8015 & $1.503 \pm 0.002$ & & $145 \pm 1$ & & $0.0084 \pm 0.0002$ & $0.6 \pm 0.01$ \\
\hline VL-D1 ${ }^{\circ} \mathbf{c}$ & \pm 0 & $7840 \pm 180$ & $1.510 \pm 0,010$ & $1.510 \pm 0,010$ & $71 \pm 18$ & $0,010 \pm 0,010$ & & 0 \\
\hline $\mathrm{CPV}-1{ }^{*} \boldsymbol{b}$ & +1.6 & $156 \pm 30$ & $1.325 \pm 0.019$ & $1.408 \pm 0.024$ & 31537 & $0.535 \pm 0.003$ & & $80.1 \pm 0.5$ \\
\hline $\mathrm{CPV}-2{ }^{*} \boldsymbol{b}$ & +1.6 & $144 \pm 28$ & $1.329 \pm 0.021$ & $1.413 \pm 0.026$ & 34757 & $0.536 \pm 0.002$ & & $80.1 \pm 0.5$ \\
\hline CPV-B8 ${ }^{*} \boldsymbol{b}$ & +1.6 & $119 \pm 18$ & $1.391 \pm 0.016$ & $1.492 \pm 0.020$ & 1812 & $0.541 \pm 0.002$ & & $81.0 \pm 0.5$ \\
\hline CPV-B6 ${ }^{*} \boldsymbol{b}$ & +2.6 & $108 \pm 20$ & $1.141 \pm 0.013$ & $1.198 \pm 0.018$ & 1892 & $0.683 \pm 0.003$ & & $120.6 \pm 0.9$ \\
\hline CPV-B9 ${ }^{*} \boldsymbol{b}$ & +2.6 & $122 \pm 14$ & $1.173 \pm 0.012$ & $1.240 \pm 0.017$ & 1151 & $0.671 \pm 0.002$ & & $116.2 \pm 0.6$ \\
\hline VL-D2 ${ }^{\circ} \mathbf{c}$ & +2.6 & $290 \pm 10$ & $1.220 \pm 0.020$ & $1.310 \pm 0.030$ & $157 \pm 47$ & $0.690 \pm 0.020$ & & $120.4 \pm 7,0$ \\
\hline \multicolumn{9}{|l|}{ \# MC-ICPMS } \\
\hline data from $T$ & nei et al (20) & b & data from Dorale et & 2010) & rom Pazzell & & & \\
\hline
\end{tabular}

day rate of relative sea level change due to GIA (Mitrovica \& Milne, 2002) indicates that GIA alone does not explain data, but another mechanism has to be additionally invoked. A minor tectonic uplift (about $1 \mathrm{~m}$ ) of the island in the last few thousand years could explain the observed discrepancy.

Older POS, now located at 1.5 and $2.6 \mathrm{~m}$ above present sea level, were U-series dated (Table 2), showing that western Mediterranean relative sea level was $~ 1$ meter above modern sea level about $81 \mathrm{ka}$ ago during marine isotope stage (MIS) $5 \mathrm{a}$ and about $2.6 \mathrm{~m}$ higher during MIS 5e (Dorale et al., 2010). The latter data are consistent with other estimates for MIS 5e in Mallorca (Tuccimei at al., 2006; Ginés et al., 2013) and other sites from around the world. The record of MIS 5 a sea level, slightly higher than at present and only slightly lower than the MIS 5e, seemingly conflicts with the eustatic sea-level curve of far-field sites and corroborate an alternative view that MIS 5a was at least as ice-free as the present (Dorale et al., 2010).

\section{CONCLUSIONS}

Cova des Pas de Vallgornera hosts a noteworthy richness in speleothems that represents one of the most important issues concerning the natural heritage values of this unique cave. The abundance and diversity of crystallizations is overwhelming throughout the cave system; they are mainly composed of calcite and to a lesser extent aragonite, along with gypsum, celestine, strontianite, nordstrandite, barite, and some other 19 minerals identified so far in this cave (Onac et al., 2014). Some typologies of speleothems hitherto unknown in Mallorca have been reported, like for instance cave rims, pool fingers and U-loops.

The arrangement of speleothems is influenced by the eogenetic character of the coastal karst from southern Mallorca, which provides depositional environments, generally marked by a quite high primary porosity. This fact has a clear repercussion on how some typologies (i.e., soda straw stalactites or helictites, for example) extensively cover the ceilings and walls of the passages and chambers.

Speleothems' distribution within the cave system is strongly conditioned by the lithologic and textural variability of the Upper Miocene reefal rocks that build up the southern coast of the island. Additionally to these geologic conditionings, other factors become involved in the distribution of some speleothem typologies as, for instance, the existence of particular morphogenetic features in specific sectors of the cave. A last factor is a merely topographic one, consisting in the existence of two main tiers developed respectively close to the current water table or around 7 to $11 \mathrm{~m}$ above it.

The referred factors determine the existence of a sharp dichotomy that allows us to consider two well-differentiated sections within the cave system, regarding the distribution of speleothems. So, in the inner landward passages, the crystallizations formed in the perched freshwater bodies existing in the upper maze are remarkable, favored by the relatively low permeability of the Upper Miocene back reef facies. Cave rims are also abundant in some passages located in the back reef carbonates, being developed on feeder-like vents of hypogene origin.

On the other hand, the seaward sectors of the cave correspond to the very porous reef front facies, where the most distinctive deposits are the phreatic overgrowths on speleothems (POS) that record stabilizations of the water table, which are sea level controlled. These carbonate encrustations have supplied valuable data on sea level during the Upper Pleistocene and Holocene.

Research on speleothems is a promising field in Cova des Pas de Vallgornera since this paper is exclusively an overview of the current knowledge on that matter. Much more work should be devoted in the future to some uncommon speleothem types represented in the cave, their mineralogy, and especially, to the paleoclimate information that could be obtained both from stalagmites and from diverse phreatic overgrowths and mammillaries that have not been studied yet. 


\section{ACKNOWLEDGEMENTS}

The authors wish to express their deep gratitude to all the cavers that with enthusiasm helped and provided support to the endless visits to the cave while collecting data and documenting speleothems. The author of all pictures (Antoni Merino) addresses special thanks to those who gave generously their time and effort to help with the photographic tasks: Toni Mulet, Anders Kristofersson, Guiem Mulet, Toni Croix, and Pau Ginés. This work is a contribution to the CGL2010-18616 investigation project of the Spanish Government.

\section{REFERENCES}

Antonioli F., Bard E., Potter E.K., Silenzi S. \& Improta S., 2004 - 215-ka history of sea-level oscillations from marine and continental layers in Argentarola Cave speleothems (Italy). Global and Planetary Change, 43: 57-78. http://dx.doi.org/10.1016/i.gloplacha.2004.02.004

Barton H.A. \& Northup D.E., 2007 - Geomicrobiology in cave environments: past, current and future perspectives. Journal of Cave and Karst Studies, 69 (1): 163-178.

Davis D.G., 2000 - Extraordinary features of Lechuguilla cave, Guadalupe Mountains, New Mexico. Journal of Caves and Karst Studies, 62: 147-157.

Davis D.G., Palmer M.V. \& Palmer A.N., 1990 Extraordinary subaqueous speleothems in Lechuguilla cave, New Mexico. NSS Bulletin, 52: 70-86.

Dorale J.A., Onac B.P., Fornós J.J., Ginés J., Ginés A., Tuccimei P. \& Peate D.W., 2010 - Sea-level highstand 81,000 years ago in Mallorca. Science, 327: 860-863. http://dx.doi.org/10.1126/science.1181725

Ford D.C. \& Williams P.W., 2007 - Karst hydrogeology and geomorphology. John Wiley \& Sons Ltd, Chichester, UK, 562 p. http://dx.doi.org/10.1002/9781118684986

Fornós J.J., Pomar L. \& Ramos Guerrero E., 2002 - Balearic Islands. In: Gibbons W. \& Moreno T. (Eds.), The Geology of Spain. London: the Geological Society: 327-334.

Fornós J.J., Merino A., Ginés J., Ginés A. \& Gràcia F., 2011 - Solutional features and cave deposits related to hypogene speleogenetic processes in a littoral cave of Mallorca Island (western Mediterranean). Carbonates and Evaporites, 26 (1): 69-81.

http://dx.doi.org/10.1007/s13146-010-0040-3

Gillieson D.S., 1996 - Caves. Processes, development, management. Blackwell Publishers, Oxford, 324 p.

Ginés A., 1995 - The speleothems of Majorcan caves. In: Ginés A. \& Ginés J. (Eds.), Karst and caves in Mallorca. Endins, 20 / Monografies de la Societat d'Història Natural de les Balears, 3: 87-97.

Ginés A., Ginés J. \& Pomar L., 1981 - Phreatic speleothems in coastal caves of Majorca (Spain) as indicators of Mediterranean Pleistocene paleolevels. Proceedings of the $8^{\text {th }}$ International Congress of Speleology, Bowling Green, USA, 2: 533-536.

Ginés A., Ginés J., Gómez-Pujol L., Onac B.P. \& Fornós J.J. (Eds.), 2012a - Mallorca: a Mediterranean Benchmark for Quaternary Studies. Monografies de la Societat d'Història Natural de les Balears, 18. Palma de Mallorca, 219 p.

Ginés A., Ginés J, Fornós J.J., Tuccimei P., Onac B.P. \& Gràcia F., 2013 - Forty years of phreatic overgrowths on speleothems (POS) research in coastal caves of Mallorca. Proceedings of the $16^{\text {th }}$ International Congress of Speleology, 2. Brno, Czech Republic: 394-399.
Ginés J., Ginés A., Fornós J.J., Merino A. \& Gràcia F., 2009a - About the genesis of an exceptional coastal cave from Mallorca Island (Western Mediterranean). The lithological control over the pattern and morphology of Cova des Pas de Vallgornera. In: White, W.B. (Ed.), Proceedings of the $15^{\text {th }}$ International Congress of Speleology, 1. Kerrville, TX: 481-487.

Ginés J., Ginés A., Fornós J.J., Merino A. \& Gràcia F., $2009 \mathrm{~b}$ - On the role of hypogene speleogenesis in shaping the coastal endokarst of southern Mallorca (Western Mediterranean). In: Klimchouk A.B. \& Ford D.C. (Eds.), Hypogene speleogenesis and karst hydrogeology of artesian basins. Ukrainian Institute of Speleology and Karstology, Special Paper, 1. Simferopol, Ukraine: 91-99.

Ginés J., Ginés A. \& Fornós J.J., 2011 - Dades sobre paleocarst $i$ espeleocronologia de les Illes Balears. In: Gràcia F., Ginés J., Pons G.X., Ginard A. \& Vicens, D. (Eds.), El carst: patrimoni natural de les Illes Balears. Endins, 35 / Monografies de la Societat d'Història Natural de les Balears, 17: 213-226.

Ginés J., Ginés A., Fornós J.J., Tuccimei P., Onac B.P. \& Gràcia F., 2012b - Phreatic Overgrowths on Speleothems (POS) from Mallorca, Spain: updating forty years of research. In: Ginés A., Ginés J., Gómez-Pujol L., Onac B.P. \& Fornós J.J. (Eds.), Mallorca: a Mediterranean benchmark for Quaternary studies. Monografies de la Societat d'Història Natural de les Balears, 18: 111-146.

Ginés J., Fornós J.J., Ginés A., Merino A. \& Gràcia F., 2014 - Geologic constraints and speleogenesis of Cova des Pas de Vallgornera, a complex coastal cave from Mallorca Island (Western Mediterranean). International Journal of Speleology, 43 (2): 105-124.

http://dx.doi.org/10.5038/1827-806X.43.2.2

Guijarro J.A., 1995 - Bioclimatic aspects of karst in Mallorca. In: Ginés A. \& Ginés J. (Eds.), Karst and caves in Mallorca. Endins, 20 / Monografies de la Societat d'Història Natural de les Balears, 3: 17-26.

Hill C. \& Forti P., 1997 - Cave minerals of the World. National Speleological Society, Huntsville, AL, 238 p.

Hodge E.J., 2004 - Palaeoclimate of the Western Mediterranean region: results from speleothems. Unpublished PhD Thesis, University of Bristol, 246 p.

Klimchouk A.B., 2007 - Hypogene speleogenesis: hydrogeological and morphogenetic perspectives. National Cave and Karst Research Institute, Special Paper 1. Carlsbad, NM, 106 p.

Melin L.A., Shinglamn K.M., Boston P.J., Northup D.E., Spilde M.N. \& Quinn J.M., 2001 - Evidence for microbial involvement in pool finger precipitation, Hidden Cave, New Mexico. Geomicrobiology Journal, 18: 311-329. http://dx.doi.org/10.1080/01490450152467813

Merino A., 2000 - Nuevas extensiones de la Cova des Pas de Vallgornera (Llucmajor, Mallorca). Endins, 23: 7-21.

Merino A., 2006 - Espeleotemas poco frecuentes y morfologias de corrosión hallados en la Cova des Pas de Vallgornera. Endins, 30: 49-70.

Merino A., 2007a - Solutional sculpturings and uncommon speleothems found in the Cova des Pas de Vallgornera, Majorca, Spain. NSS News, 65 (9): 14-20.

Merino A., 2007b - Algunos espeleotemas poco habituales hallados en la Cova des Pas de Vallgornera. Nuevas observaciones. Endins, 31: 111-116.

Merino A., 2008 - Nueva aportación al conocimiento de los espeleotemas y morfologías existentes en la Cova des Pas de Vallgornera. Endins, 32: 43-48.

Merino A. \& Fornós J.J., 2010a - Presencia de Pool Fingers y U-loops en la Cova des Pas de Vallgornera (Mallorca, España). Endins, 34: 103-107.

Merino A. \& Fornós J.J., 2010b - Los conjuntos morfológicos de flujo ascendente (morphologic suite of rising flow) en la Cova des Pas de Vallgornera (Llucmajor, Mallorca). Endins, 34: 85-100. 
Merino A., Mulet A. \& Mulet G., 2006 - La Cova des Pas de Vallgornera: 23 kilómetros de desarrollo topografiado (Llucmajor, Mallorca). Endins, 30: 29-48.

Merino A., Fornós J.J. \& Onac B.P., 2009 - Preliminary data on mineralogical aspects of cave rims and vents in Cova des Pas de Vallgornera, Mallorca. In: White W.B. (Ed.), Proceedings of the $15^{\text {th }}$ International Congress of Speleology, 1. Kerrville: National Speleological Society: 307-311.

Merino A., Fornós, J.J. \& Ginés, A., 2011 - Espeleotemes $i$ minerals de les coves de les Illes Balears. In: Gràcia F., Ginés J., Pons G.X., Ginard A. \& Vicens, D. (Eds.), El carst: patrimoni natural de les Illes Balears. Endins, 35 / Monografies de la Societat d'Història Natural de les Balears 17: 183-198.

Merino A., Mulet A., Mulet G., Croix J.A., Kristofersson A., Gràcia F. \& Perelló M.A., 2014 - Cova des Pas de Vallgornera (Mallorca, Spain): History of exploration and cave description. International Journal of Speleology, 43 (2): 95-104. http://dx.doi.org/10.5038/1827-806X.43.2.1

Mitrovica J.X. \& Milne G.A., 2002 - On the origin of late Holocene sea-level high stands within equatorial ocean basins. Quaternary Science Reviews, 21: 2179-2190.

Northup D.E., Dahm C.N., Melin L.A., Spilde M.N., Crossey L.J., Lavoie K.H., Mallory L., Boston P.J., Cunningham K.I. \& Barns S.M., 2000 - Evidence of geomicrobiological interactions in Guadalupe (NM) caves. Journal of Cave and Karst Studies, 62: 80-90.

Northup D.E., Barns S.M., Yu L.E., Spilde M.N., Schelble R.T., Dano K.E., Crossey L.J., Connolly C.A., Boston P.J., Natvig D.O. \& Dahm C.N., 2003 - Diverse microbial communities inhabiting ferromanganese deposits in Lechuguilla and Spider caves. Environmental Microbiology, 5: 1071-1086.

Onac B.P., Fornós J.J., Merino A., Ginés J., Dieh1 J., 2014 - Linking mineral deposits to speleogenetic processes in Cova des Pas de Vallgornera (Mallorca, Spain). International Journal of Speleology, 43 (2): 143-157. http://dx.doi.org/10.5038/1827-806X.43.2.4

Palmer A.N., 2007 - Cave geology. Cave Books. Dayton, Ohio, 454 p.

Pazzelli L., 1999-Variazionidel livello delmarenelMediterraneo occidentale durante il Tardo Pleistocene, misurate attraverso la datazione U/Th di concrezioni freatiche su speleotemi sommersi nelle grotte costriere dell'Isola di Mallorca (Spagna). Tesi di Laurea in Scienze Geologiche presso l'Università degli Studi "Roma Tre", 114 p.

Pomar L., Ginés A. \& Ginés J., 1979 - Morfologia, estructura y origen de los espeleotemas epiacuaticos. Endins, 5-6: 3-17.

Pomar L., Ward W.C. \& Green D.G., 1996 - Upper Miocene reef complex of the Llucmajor area, Mallorca, Spain. In: Franseen E., Esteban M., Ward W.C. \& Rouchy J.M. (Eds.), Models for carbonate stratigraphy from Miocene reef complexes of the Mediterranean regions. SEPM Concepts in Sedimentology and Paleontology, 5: 191-225.

Spada G. \& Stocchi P., 2007 - SELEN: a Fortran 90 program for solving the "Sea Level Equation". Computers \& Geosciences, 33: 538-562. http://dx.doi.org/10.1016/j.cageo.2006.08.006
Spilde M.N., Northup D.E., Boston P.J., Schelble R.T., Dano K.E., Crossey L.J. \& Dahm C.N., 2005-Geomicrobiology of cave ferromanganese deposits: a field and laboratory investigation. Geomicrobiological Journal, 22: 99-116. http:/ /dx.doi.org/10.1080/01490450590945889

Spilde M.N., Northup D.E. \& Boston P.J., 2006 Ferromanganese deposits in the caves of the Guadalupe Mountains. New Mexico Geological Society, Guidebook $57^{\text {th }}$ Field Conference. Caves and Karst of Southeastern New Mexico.

Sweeting M.M., 1973 - Karst landforms. Columbia University Press, New York, 362 p.

Tuccimei P., Ginés J., Delitala C., Ginés A., Gràcia F., Fornós J.J. \& Taddeucci A., 2006 - Last interglacial sea level changes in Mallorca island (Western Mediterranean). High precision Useries data from phreatic overgrowths on speleothems. Zeitschrift für Geomorphologie, 50 (1): 1-21.

Tuccimei P., Soligo M., Ginés J., Ginés A., Fornós J.J., Kramers J. \& Villa I.M., 2010 - Constraining Holocene sea levels using U-Th ages of phreatic overgrowths on speleothems from coastal caves in Mallorca (Western Mediterranean). Earth Surface Processes and Landforms, 35 (7): 782-790.

Tuccimei P., Van Strydonck M., Ginés A., Ginés J., Soligo M., Villa I.M.\& Fornós J.J., 2011 - Comparison of ${ }^{14} \mathrm{C}$ and $U$-Th ages of two Holocene phreatic overgrowths on speleothems from Mallorca (Western Mediterranean): environmental implications. International Journal of Speleology, 40 (1): 1-8. http://dx.doi.org/10.5038/1827-806X.40.1.1

Tuccimei P., Onac B.P., Dorale J.A., Ginés J., Fornós J.J., Ginés A., Spada G., Ruggieri G. \& Mucedda M., 2012 - Decoding last interglacial sea-level variations in the western Mediterranean using speleothem encrustations from coastal caves in Mallorca and Sardinia: a field data - model comparison. Quaternary International, 262: 5664. http://dx.doi.org/10.1016/j.quaint.2011.10.032

Tuccimei P., Soligo M., Fornós J.J., Ginés A., Ginés J., Spada G., Villa I.M. \& Onac B.P. 2013 - Late Holocene sea-level record in Mallorca inferrred from U-Th dating of overgrowths on speleothems: implications for GIA models in the Western Mediterranean. Proceedings of the $10^{\text {th }}$ Applied Isotope Geochemistry Conference, Budapest. Central European Geology, 56 (2-3): 74-75.

Vacher H.L. \& Mylroie J.E., 2002 - Eogenetic karst from the perspective of an equivalent porous medium. Carbonates and Evaporites, 17 (2): 182-196. http://dx.doi.org/10.1007/BF03176484

Vesica P.L., Tuccimei P., Turi B., Fornós J.J., Ginés A. \& Ginés J., 2000 - Late Pleistocene paleoclimates and sea-level change in the Mediterranean as inferred from stable isotope and U-Series studies of overgrowths on speleothems, Mallorca (Spain). Quaternary Sciences Reviews, 19 (9): 865-879.

White W.B., 1976 - Cave minerals and speleothems. In: Ford T.D. \& Cullingford C.H.D. (Eds.), The Science of Speleology. London: Academic Press: 267-327. 